Portland State University

PDXScholar

$10-7-1980$

\title{
A Comparison of Spanish Language Samples Elicited by the Investigator in the Clinic and by the Mothers in the Home
}

Soledad Chavarria Navas

Portland State University

Follow this and additional works at: https://pdxscholar.library.pdx.edu/open_access_etds

Part of the Spanish Linguistics Commons, Speech Pathology and Audiology Commons, and the Syntax Commons

Let us know how access to this document benefits you.

\section{Recommended Citation}

Chavarria Navas, Soledad, "A Comparison of Spanish Language Samples Elicited by the Investigator in the Clinic and by the Mothers in the Home" (1980). Dissertations and Theses. Paper 3009.

https://doi.org/10.15760/etd.2986

This Thesis is brought to you for free and open access. It has been accepted for inclusion in Dissertations and Theses by an authorized administrator of PDXScholar. Please contact us if we can make this document more accessible: pdxscholar@pdx.edu. 
AN ABSTRACT OF THE THESIS OF Soledad Chavarria Navas for the Master of Science in Speech Communication, with an emphasis in Speech Pathology/ Audiology, Presented October 7, 1980.

Title: A Comparison of Spanish Language Samples Elicited by the Investigator in the Clinic and by the Mothers in the Home.

APPROVED BY MEMBERS OF THE THESIS COMMITTEE:

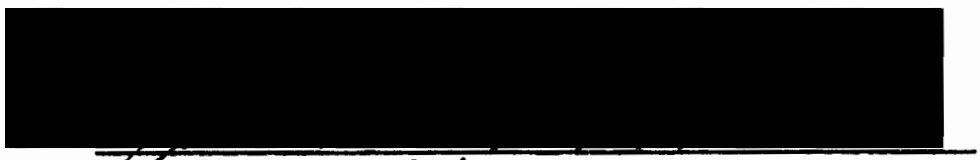

JGan McMahon, Chairperson

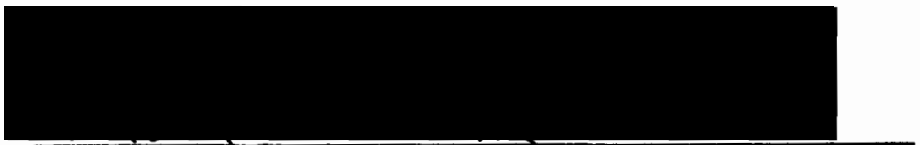

Mary E. Gdrdon

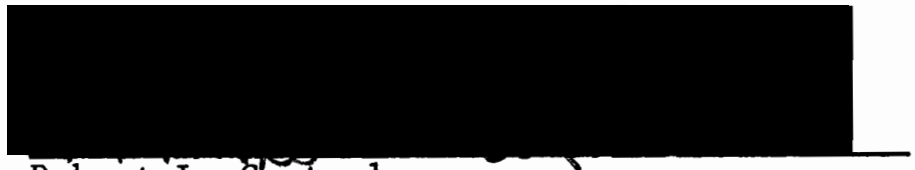

Robert L. Castee 1

A common denominator to most studies concerning language acquisition is the elicitation of a corpus of a given number of spontaneous utterances which are representative of the child's linguistic maturity. This procedure, also called language sampling, is used daily by speech clinicians in their efforts to evaluate a child's language maturity and complexity.

Language samples are elicited and analyzed in the Hispanic countries without the availability of specific norms or procedures. Research considering the effects of different variables on the language 
sample, i.e., the possible differences between language samples elicited by mothers in the home setting and by clinicians in the clinic or school setting, is non-existent.

The primary purpose of the present study was to compare the quality of spontaneous language samples elicited from twelve low socioeconomic, normally developing, migrant Spanish-speaking subjects by their mothers in the home and by this investigator in the clinic. The subjects ranged in age from three years, one month to six years, nine months.

The essential question sought to determine if the comparison of language samples elicited in the home by the mothers and the language samples.elicited in the clinic by the investigator yielded significant differences in syntactical language development as measured by the Developmental Assessment of Spanish Grammar (DASG) (Toronto, 1972, 1976). Comparison of DASG total scores and DASG individual category scores was made between the home and the clinic samples. Mean scores were determined for the subjects' performances in each setting. Differences between the means of the different results were analyzed utilizing a t-test. In addition, t-test analysis was conducted to determine the significance level of DASG scores when compared by age and sex in the clinic and in the home, and by order of examination.

Results of the study indicated no statistically significant differences between the samples elicited in the clinic and in the home by the investigator and the mothers, although the subjects utilized more complex sentences in the home than in the clinic as demonstrated by the higher scores obtained in the Indefinite Pronouns and Noun Modifiers, 
Personal Pronouns, Primary Verbs, and Secondary Verbs categories. No statistically significant differences were found between sexes and the comparison of DASG scores by order of examination. Results of the comparison between age groups indicated a statistically significant difference in favor of the oldest group (Group IV; age range 6.8 to 6.9) when compared to a younger group (Group III; age range 5.2 to 5.10). A comparison of amount of responses elicited in a 15-minute period indicated a trend in favor of the investigator.

The results of the present study appear to support findings of studies conducted with English-speaking subjects. Although the speechlanguage clinician may elicit greater amounts of speech, there is a slight difference in favor of the quality of the language samples elicited by the mother in the home. This difference, however, is not statistically significant and does not invalidate those samples taken in the clinic. This author, therefore, believes that in terms of the Spanish-speaking population involved in this study, if a clinician invests time prior to the sample elicitation, the language samples elicited in the clinic setting may be considered to be representative of linguistic maturity. 
A COMPARISON OF SPANISH LANGUAGE SAMPLES ELICITED BY THE INVESTIGATOR IN THE CLINIC AND BY THE

MOTHERS IN THE HOME

$$
\text { by }
$$

SOLEDAD CHAVARRIA NAVAS
A thesis submitted in partial fulfillment of the requirements for the degree of

\author{
MASTER OF SCIENCE IN SPEECH COMMUNICATION: \\ with an emphasis in \\ SPEECH PATHOLOGY/AUDIOLOGY
}

\author{
Portland State University \\ 1980
}


TO THE OFFICE OF GRADUATE STUDIES AND RESEARCH:

The members of the Committee approve the thesis of Soledad Chavarria Navas presented October 7, 1980.

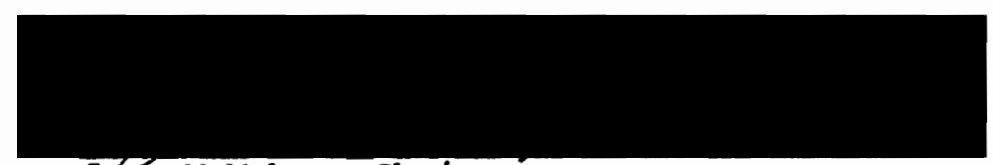

Joan McMahon, Chairperson

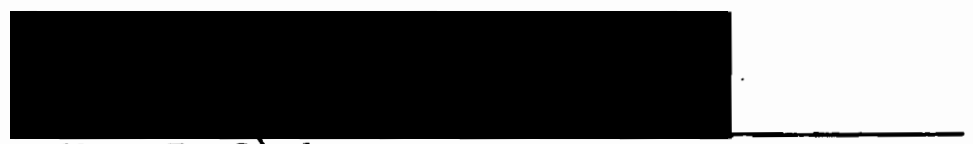

Mary E. Ggrdon

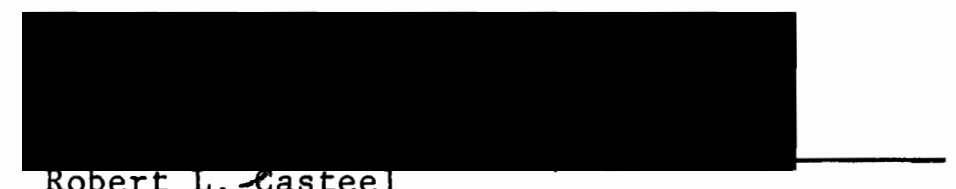

APPROVED :
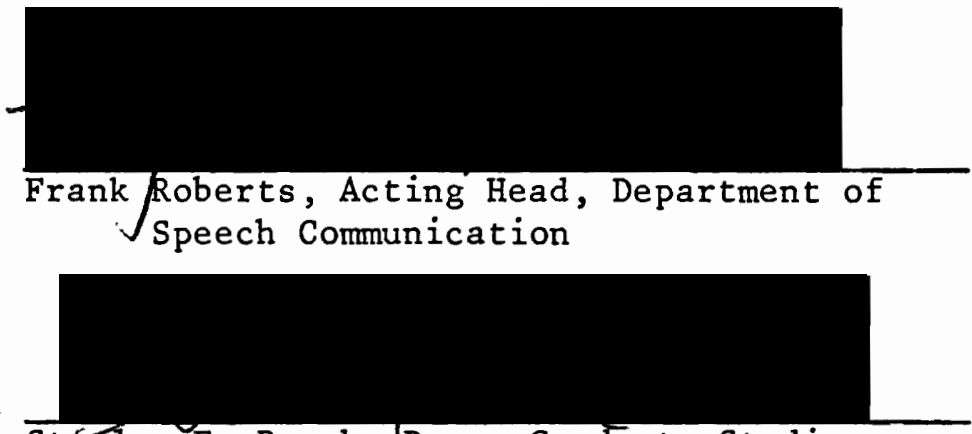

St䄮ley E. Rauch, Đean, Graduate Studies and Research 


\section{DEDICAT ION}

This thesis is dedicated to four people who have been very important to my personal growth: my parents and Mima, who, although deceased, live forever in my heart; and Joan McMahon, my academic advisor, my thesis director, but above all my friend, a marvelous human being always ready to 1 isten and help. Thank you, Joan! I owe this thesis totally to you. 


\section{ACKNOWLEDGMENTS}

From April 1978 until the moment this thesis is ready to be printed in the Fall of 1980, many events have affected my personal/ professional life. All of you who were and are with me know what I am referring to. Yes, to you, my family and friends in Costa Rica, Buffalo (New York), Oregon, Seattle, Colombia, and Ecuador I owe completion of this undertaking, begun May 11, 1978 and culminating today, October 7, 1980. Your moral support (and at times economic), your love, and your faith in me were indispensable each moment. Thanks!

This thesis could not have been written without the collaboration of the parents, children, and staff of Woodburn Children's

Center (Woodburn, Oregon). To them I am eternally grateful for many hours of work dedicated to this study.

Feelings are always better expressed in one's native language. Thus, this section of my thesis was written first in Spanish and then translated into English by Sandy Orlando. Sandy, Gracias! Your letters and your two-hour phone calls (from Buffalo, New York-WOW!) always gave me the incentive to continue ahead with this incredible Master's program of ninety-five credit hours!

Last, but not least, I express my gratitude to:

Dr. "E," who in vain struggled to teach me to write in English. Dr. Casteel, who embarked me on many things I really did not want to do. . but from whom I learned to be a better professional. 
Mary Gordon whose millions of "why's" and other pertinent questions and comments in my lesson plans, summaries, and thesis taught me to think before writing a sentence. No wonder it took hours to finish up a final summary!

Georgie Hustead, who taught me not only to be a good "stuttering clinician" but also to treat myself as a better person.

Kerry Lewis, from whom I learned the importance of always maintaining open communication.

Dr. Maurer, "responsible" for my presence at Portland State University. His help toward my trip to Costa Rica in 1979 and his concern for my health are very deeply appreciated.

Shary Kazdoy, the person, the professor, whose youth does not impede her from being a professional with vast educational experience in teaching and rehabilitation techniques for the deaf and the hearing impaired.

Ted Grove, whose accurate comments on Chapter III of this thesis certainly improved the quality of this study.

To all of you, my friends, my love! 
TABLE OF CONTENTS

Page

DEDICATION . . . . . . . . . . . . . . .

ACKNOWLEDGMENTS ................... . . . . iv

LIST OF TABLES .................... . . . viii

LIST OF FIGURES . . . . . . . . . . . . . . . . ix ix

CHAPTER

I INTRODUCTION AND STATEMENT OF PURPOSE . . . . . . 1

Introduction ............. . . 1

Statement of Purpose ........... 3

II REVIEW OF THE LITERATURE . . . . . . . . . . . 4

Studies of General Language Acquisition..... 5

The Language Sample . . . . . . . . . 6

Evaluation of Length and Complexity of the

Child's Verbal Productions . . . . . . 8

Studies of Spanish Language Acquisition . . . . 10

The Language Sample in the Hispanic Countries . . 13

III METHODS AND PROCEDURES . . . . . . . . . . . 17

Subjects .............. . . 17

Socioeconomic Status (SES)

Housing

Education

Income

Examiners ...............

Instrumentation . . . . . . . . . . 
Procedures . . . . . . . . . . . . .

Language Sample Collection

Sample Collection at Home

Sample Collection at the Clinic

Data Scoring and Analysis . . . . . . . . .

IV RESULTS AND DISCUSSION . . . . . . . . . . .

Results... . . . . . . . . . . . . 25

Discussion . . . . . . . . . . . . . 34

$\mathrm{V}$ SUMMARY AND IMPLICATIONS . . . . . . . . . . . . . 51

Summary ................. . . 51

Implications for Clinic and Future Research . . . 53

Clinical Implications

Research Implications

BIBLIOGRAPHY

A CONSENT FORM FOR PARTICIPATION OF THE CHILD . . . . . 61

B CONSENT FORM FOR PARTICIPATION OF THE MOTHER . . . .

C INSTRUCCIONES PARA LA MADRE SOBRE COMO EVOCAR UNA MUESTRA DE LENGUAJE . . . . . . . . . . . 64

D DASG CATEGORIES AND WEIGHTED SCORES $\quad$ - . . . . •

E DEVELOPMENTAL ASSESSMENT OF SPANISH GRAMMAR SCORE SHEET . . . . . . . . . . . . . . .

F TYPICAL LANGUAGE SAMPLE ELICITED BY THE MOTHER

IN THE HOME . . . . . . . . . . . . . . .

G TYPICAL LANGUAGE SAMPLE ELICITED BY THE INVESTIGATOR

IN THE CLINIC . . . . . . . . . . . . . . . . . . 


\section{LIST OF TABLES}

TABLE

Page

I DASG Scores Obtained in the Clinic and in the Home . .

II Comparison of Mean DASG Scores Obtained in the

clinic and in the Home . . . . . . . . . . . .

III Comparison of Mean Scores of Each DASG Category

Obtained in the Clinic and in the Home . . . . .

IV Comparison of DASG Scores by Age in the Clinic and in the Home.. . . . . . . . . . . . . . .

$\mathrm{V}$ Comparison of Mean DASG Scores between Age Groups in the Clinic and in the Home . . . . . . . . . . .

VI Comparison of Mean DASG Scores by Sex in the Clinic and in the Home .. . . . . . . . . . .

VII Comparison of Mean DASG Scores between Sex Groups in the Clinic and in the Home . . . . . . . . .

VIII Comparison of Mean DASG Score Obtained by the Group of 12 Subjects in the First and the Second Examinations . . . . . . . . . . . . .

IX Comparison between DASG Norms and DASG Scores Obtained in the Clinic and in the Home . . . . .

$\mathrm{X}$ Actual Time and Amount of Utterances by Each Subject obtained in the Clinic and in the Home . . . . .

XI Amount of Utterances by Each Subject Obtained in the Clinic and in the Home in a 15-Minute Period. 


\section{LIST OF FIGURES}

FIGURE

Page

1 Comparison of DASG scores by the group of 12 subjects in the clinic and in the home......

2 Comparison of DASG scores obtained in the clinic and in the home . . . . . . . . . . . . . .

3 Comparison of mean DASG score for each category in the clinic and in the home . . . . . . . 38

4 Comparison of mean DASG scores by age in the clinic and in the home . . . . . . . . . . . .

5 Comparison of mean DASG scores by sex in the clinic and in the home... . . . . . . . .

6 Comparison of the DASG score of each subject between the first and the second examinations . . 
CHAPTER I

INTRODUCTION AND STATEMENT OF PURPOSE

\section{Introduction}

Acquisition and development of language have been the major concern of many investigators in the past two centuries. Studies, at first rudimentary and limited, evolved toward more systematic and sophisticated forms with McCarthy (1930), Templin (1957), Chomsky (1969), Bloom (1970), and Brown (1973).

A common denominator to most studies concerning language acquisition is the elicitation of a corpus of a given number of spontaneous utterances which are representative of the child's linguistic maturity. This procedure, also called language sampling, is used daily by speech clinicians in their efforts to evaluate a child's language maturity and complexity.

Representativeness of the child's language maturity and complexity evaluated through a language sample has led the investigators to address themselves to the question of the validity of the sample when variables, such as examiner, materials, and environment, may affect the child's performance. Numerous studies have been conducted to clarify the issue (Cowan, Weber, Hoddinot, and Klein, 1967; Casteel, 1969; Wilson, 1969; Mathis, 1970; Nelson, 1972; Longhurst and Schrandt, 1973; Longhurst and Grubb, 1974; Longhurst and File, 1975; Scott, Taylor, and White, 1978; 01swang and Carpenter, 1978; James, 
1978; and Kramer, James, and Saxman, 1979). The results of these studies indicate that language samples elicited in a clinic or at school by the clinician have been shown to be representative of the child's linguistic maturity.

Procedures, such as the Mean Length of Response (MLR) (McCarthy, 1930), Mean Length of Utterance in Morphemes (MLU) (Brown, 1973), and the Developmental Sentence Analysis (DSA) (Lee, 1974), among others, have been developed to measure length, complexity, and syntactic knowledge. These measures not only have allowed the clinician or investigator to make an analysis of the elicited language sample but also to make a comparison of language samples elicited by different investigators in different environments.

The above-mentioned studies of language acquisition have involved only English-speaking children and have been conducted by Englishspeaking investigators. Very little research in Spanish speech and language acquisition is found in the available literature. Isolated studies have been made in Argentina (De Quiros, 1972), Mexico (De Gonzalez, 1976), Puerto Rico (Linares-Orana and Sanders, 1977), and the United States (Toronto, 1972, 1976). Toronto has developed the Developmental Assessment of Spanish Grammar (DASG), the only known procedure devised to analyze syntactically the language samples elicited from Spanish-speaking children.

Language samples are elicited and analyzed in the Hispanic countries without the availability of specific norms or procedures. Research considering the effects of different variables on the language sample, i.e., the possible differences between language samples elicited by mothers in the home setting and by clinicians in the clinic 
or school setting, is non-existent as reported by Herrera Orozco (1979), Trejos de Lafendt (1980), and Solano de Araya (1980). The paucity of research in language acquisition and analysis and comparison of language samples in Spanish give importance to this pioneer study in order to establish a basis for systematic analysis of the language sample and the variables acting upon it. This will result in increased knowledge of Spanish speech and language acquisition.

\section{Statement of Purpose}

The purpose of this investigation was to compare the quality of spontaneous language samples elicited from Spanish-speaking children by their mothers in the home and by this investigator in the clinical setting.

The essential question to answer was:

Are there any significant differences, as measured by the Developmental Assessment of Spanish Grammar (DASG), in language samples elicited from normal Spanishspeaking children by the mothers in the home and a Spanish-speaking clinician in the clinical setting? 
CHAPTER II

\section{REVIEW OF THE LITERATURE}

Acquisition of language by children is an issue which has been constantly addressed by those in the disciplines involved in the study of human communication. As reported by Dale (1976), the first studies, conducted as early as the eighteenth and nineteenth centuries, were merely descriptions of the extent of vocabulary of individual children. Typical of these studies were Tiedmann's diary of infant behavior published in 1787 and Darwin's observations on his children published in $1877^{\circ}$ (Dale, 1976).

Research in language acquisition became more systematic with investigations such as those of McCarthy (1930, 1954), Dewey (1935), Davis (1937), Schneidermann (1955), Templin (1957), Winitz (1959), Cowan, Weber, Hoddinot, and Klein (1967), Kirk, McCarthy, and Kirk (1969), Chomsky (1969), and Brown (1973). Parameters analyzed by these investigators ranged from general acquisition of language to specific aspects such as onset of first words, order and rate of appearance of speech sounds, psycholinguistic abilities, acquisition of syntax, and emergence of the first sentences.

Language investigators also have been concerned with accurate measurement of the child's utterances. Studies have been completed by numerous authors evaluating general language acquisition and/or length and complexity of the child's verbal productions (McCarthy, 1930, 
1954; Davis, 1937; Templin, 1957; Shriner, 1967; Brown, 1973; and Lee, 1974).

\section{Studies of General Language Acquisition}

In 1926, Piaget introduced the analysis of children's language according to the function of their responses in relation to their environment. He influenced many of the major investigations regarding language development and his model, developed to explain the cognitive processes of the child, was first utilized in the United States by McCarthy in 1930 (McCarthy, 1930).

McCarthy's 1930 study modified Piaget's model to fit the circumstances under which she made her observation and allowed for more detailed analysis (Johnson, Darley, and Spreisterbach, 1963). McCarthy developed a set of rules for identifying an utterance and counting the words in each response with regard to gramatical complexity and completeness (Darley and Mol1, 1960).

Templin (1957) conducted extensive research on language acquisition. Her purpose was twofold: 1) to describe the growth of four aspects of language of children from three to eight years of age, and 2) to investigate the correlation of these aspects of language over the age range studied. Results from her study led Templin (1957) to remodel McCarthy's proposed categories for grammatical complexity and completeness and to propose a new weighted system for sentence scoring.

A common denominator to language studies is the technique in which a minimum of fifty utterances were analyzed for each subject. 
This procedure, known as the language sample, has been studied by numerous investigators.

\section{The Language Sample}

Representativeness of the language sample and the different variables affecting the spontaneity of the child's utterances has been the concern of numerous investigators, and abundant research is found in the literature. Situational variables such as the topic, the formality of the situation, the elicitor, and the elicitor-environment, have been studied by Cowan et a1., 1967; Castee1, 1969; Wilson, 1969; Mathis, 1970; Nelson, 1972; Longhurst and Schrandt, 1973; Longhurst and Grubb, 1974; Longhurst and File, 1975; Scott et a1., 1978; 01swang and Carpenter, 1978; James, 1978; and Kramer et a1., 1979.

In discussing the variable of the formality of the situation, Labov (1970) believes that children's spontaneous language is hindered by the presence of adults, especially those who are impatiently trying to elicit speech for tests or research purposes. He states that the structure of testing and obtaining speech samples actually keeps children from performing to their actual capacity. He reports, however, in a non-structured speaking situation with peers or animals, they may perform at or above age level.

The formality of the situation also has been investigated in two different studies by Longhurst and his colleagues. Subjects of the Longhurst and colleagues's studies were mentally retarded children (Longhurst and Grubb, 1974) and children of a Head Start Program in Kansas (Longhurst and File, 1975). Four different ways of eliciting language were presented to the children. Findings of both studies 
concur that less structured procedures resulted in better and more typical language samples than the structured situations. Scott et al. (1978) conducted an investigation to determine whether clinic language samples collected in the context of an unstructured clinician-child conversational exchange are representative of a normal child's linguistic productivity. The validity of the language sample collected in the clinical setting by the clinician was compared with the language sample collected by the mother in the home. The authors concluded unstructured clinic language samples in which a conversational setting is established are representative of the child's linguistic knowledge.

Other variables affecting the results of the language sample may be the elicitor and the interaction between the elicitor and the environment in which the language sample is being elicited. Casteel (1969) questioned the consequences resulting from different examiners in different settings. He found that "when considering the interaction of examiner and setting there are significant differences in performances between familiar setting and clinical setting." Casteel (1969) further stated:

There seems to be a strong need for the adult to be comfortable in the setting. It would seem reasonable to conclude that, other things being equal, the best results on language assessment would be gained by the speech pathologist in the clinic and by the mother in the home.

Mathis (1970) compared the language output of normal children elicited by a speech pathologist in the clinical setting with the language output of the same children elicited by the mother in the home. Her findings indicate a trend for the speech pathologist to elicit greater 
amounts of verbal output than the mothers, although the differences were not statistically significant. Olswang and Carpenter (1978) examined the effects of the elicitor on the language sample obtained from nine language-impaired children. The language samples were taken by mothers and clinicians in the clinical setting. The authors concluded clinicians should "feel confident in their ability to elicit as qualitatively good a language sample from a young child as the child's mother." Kramer et al. (1979) conducted the most recent investigation reported in the literature in which the effects of elicitor-environment variability are investigated. They addressed the question of the representativeness of the language sample collected from language-impaired children in the clinical setting by the speechlanguage clinician as compared to language samples obtained in the home by the mother. Results showed the children produced longer utterances at home, although there were no syntactic differences between the clinic and home gathered samples. They concluded language samples elicited from language delayed children in the clinic room by the clinician are representative of the child's linguistic ability.

The review of the available literature has demonstrated the value of the language sample as a clinical procedure. Several methods have been developed to analyze the resultant language samples.

\section{Evaluation of Length and Complexity of the Child's Verbal Productions}

Measurements to evaluate length and/or complexity of child's utterances in a language sample have been proposed and developed by several authors (McCarthy, 1930; Templin, 1957; Shriner, 1967; Brown, 
1973; and Lee, 1974).

Among measures to evaluate length, the Mean Length of Response

(MLR) (McCarthy, 1930) has been one of the most commonly used by investigators and clinicians. MLR was first advocated by Nice (1926) and then utilized by McCarthy in 1930 in her analysis of length of response, complexity of sentence structure, function of the response, and proportions of various parts of speech. McCarthy (1954) stated that MLR seems to be a "reliable, easily determined, objective, quantitative, and easily understood measure of linguistic maturity."

Other measures of sentence length reported in the literature are the Mean of the Five Longest Responses (MSL) (Davis, 1937) and the Number of One Word Utterances (N1W) (Davis, 1937). The M5L may represent the child's linguistic ability in a given situation and Davis (1937) and Templin (1957) concur that a decreasing number of one-word responses in child's language behavior may be an indicator of the child's linguistic maturity.

One of the measures for sentence complexity is the Structural Complexity Score (SCS) developed by Templin in 1957. Templin (1957), in an attempt to measure the complexity of language structure, assigned weights to various sentence types in a corpus of fifty sentences and derived a Structural Complexity Score (SCS).

The Length-Complexity Index (LCI) was developed by Shriner (1967). It was designed to measure both sentence length and complexity of a corpus of fifty utterances, according to a numeric weighting system (Barlow, 1969).

In 1973, Brown introduced the Mean Length of Utterance in 
Morphemes (MLU). As defined by Dale (1976), MLU is the average length of the child's utterance in morphemes. Computation of $\underline{M U}$ is based upon fifty utterances from a corpus of one hundred.

The Developmental Sentence Analysis was developed by Lee and Canter in 1971 and published by Lee in 1974. As defined by Lee (1974), Developmental Sentence Analys is (DSA) is:

A method for making a detailed, readily quantified and scored evaluation of a child's use of standard English grammatical rules from a tape-recorded sample of his spontaneous speech in conversation with an adult, in this case with his/her clinician.

The DSA is the common name for two evaluational procedures, the Developmental Sentence Types (DST) and the Developmental Sentence Score (DSS). The DST evaluates pre-sentence structures, those utterances in which only partial subject-verb grammatical structures are found. The DSS analyzes utterances in which subject-verb relationships are found.

The preceding sections of this review have considered studies of general acquisition of language, the strategy common to these studies in order to obtain the data, and the different techniques developed to analyze these data. Common to the above studies is the, focus on the language acquisition of English-speaking children and the research conducted by English-speaking investigators. As the present investigation deals with Spanish-speaking subjects, a review of the available literature of Spanish language acquisition is in order.

\section{Studies of Spanish Language Acquisition}

The available literature on Spanish language acquisition is not 
as extensive as the literature found on English language acquisition. Isolated studies have been made in some countries of Latin America. Studies of language acquisition on Spanish-speaking children have been carried out in the Instituto de Investigaciones Otoneurofoniatricas of Buenos Aires, Argentina, by De Quiros and colleagues, beginning more than twenty years ago. Their work, strongly influenced by Piaget (1926), McCarthy (1930), and Gessel (1940), is more a discussion of language models than an analysis of how Spanish-speaking children master their speech and language.

A study of the developmental acquisition of phonemes was made in Mexico by De Gonzalez (1976). Two hundred children were the subjects of her research. Ages ranged between three and six years old. Children were to name pictures in which the investigated phoneme was in initial, middle, and final positions. De Gonzalez's results do not vary from McCarthy's or Templin's norms of phoneme acquisition and, therefore, the latter are still used for comparison of children's speech acquisition in Spanish-speaking countries.

$$
\text { Linares-Orana (1975) and Linares-Orana and Sanders (1977) }
$$

reported studies in which the syntax of sixty three-year-old Spanishspeaking Puerto Rican children was evaluated. In the first study, MLU, as adapted to Spanish by Linares-Orana, was utilized to analyze children's language samples. In the second study the Developmental Assessment of Spanish Grammar (DASG) (Toronto, 1972, 1976) and the MLU were the measures by which the data were analyzed. Results from the studies showed that all subjects, regardless of age or language status, demonstrated greatest proficiency in use of conjunctions, 
followed by indefinite pronouns and noun modifiers, with lesser proficiency in secondary verbs, primary verbs, personal pronouns, and interrogative words.

As stated earlier, only a few studies of Spanish language acquisition have been conducted in Latin American countries. Most of the research available in the current literature has been carried out in the United States. These included many in-depth studies of phonology, dialects, syntax, evolution of the language, and bilingualism, but most of these studies deal with the language which is already established in the adult (Toronto, 1972). Examples of these studies are those conducted by Garcia (1975), Broke1 (1979), Lawton (1979), and Lindholm and Padilla (1979).

Based on Chomsky's theory of language universals, some authors have attempted to apply the English rules of transformational grammar to those of Spanish in their search for a psycholinguistic explanation of the development and acquisition of this language. Their research has covered acquisition of verbs (Kernan and Blount, 1966), syntactic and morphologic development (Kernan and Blount, 1966), Spanish transformational grammar (Contreras, 1967), and acquisition of Spanish grammar by children (Gonzalez, 1970). These investigations set the theoretical framework for the development by Toronto of the first two standardized measures of Spanish language acquisition: the Developmental Assessment of Spanish Grammar (DASG) (1972), and the Screening Test of Spanish Grammar (1973). The DASG, which is directly related to the present investigation, will be considered in further detail in this review. 
The studies of Toronto (1972, 1973, 1976), Linares-Orana (1975), and Linares-Orana and Sanders (1977) included the elicitation of language samples from children. As stated previously in this review, the language sample has been essential to research in the acquisition of language and to clinical evaluations. The state of this procedure in the Hispanic countries as a research and clinical tool is discussed in the next section of this review.

\section{The Language Sample in the Hispanic Countries}

Review of the available literature reveals no research has been conducted in Latin America regarding the validity, representativeness, or variables affecting the language sample. The literature also points out there is no suggested standard tool to evaluate children's utterances in those countries. To the knowledge of this writer and as reported by Herrera Orozco (1979), Solano de Araya (1980), and Trejos de Lafendt (1980), language samples are taken as part of a diagnostic procedure but do not follow standardized procedures in eliciting the samples or comparing them to the norms. The collected data are usually compared either to Gessel's (1940), Gessel and Amatruda's (1947), or McCarthy's (1930) tables of "normal" language acquisition and/or the child is simply labeled as "normal" or "delayed" according to the clinician's judgment (Solano de Araya, 1980; and Trejos de Lafendt, 1980). Research and scientific analysis of the language sample appear to be a prime need for Spanish-speaking countries.

Again it is in the United States where investigations on this topic have been carried out. Due to the increase of Spanish-speaking populations attending the public schools of this country, the neces- 
sity for developing adequate diagnostic tools of language acquisition for Hispanic children was pointed out by speech pathologists (Rueda and Perozzi, 1977). As a result of this need, various measures were proposed but all had the serious limitation of being direct translations from English to Spanish (Rueda and Perozzi, 1977).

In 1972 and 1973, Toronto published the first measures standardized in a Spanish-speaking population: the Developmental Assessment of Spanish Grammar (DASG) and the Screening Test of Spanish Grammar (STSG). Since the STSG does not utilize a language sample, the DASG is the only measurement method for language samples reported in the 1iterature.

The DASG (Toronto, 1972) was developed in Chicago as a result of the great necessity for normative data on the acquisition of the Spanish language by bilingual children attending the public schools of that area. Its use, however, has spread over the bilingual areas of the United States and Puerto Rico. The Screening Test of Spanish Grammar (STSG) and the DASG constitute the most commonly used procedures to assess the syntax of Spanish-speaking children (Ratusnik, Ratusnik, and Sattinger, 1978).

The DASG was originally developed using a population of 48 norma1, Spanish-speaking Mexican-American children. Standardization in 1976 was accomplished utilizing 64 Mexican children and 64 Puerto Rican children between the ages of 3.0 and 6.11 years. Toronto (1976) found no significant differences between the performances of these two ethnic groups whose dialects were considerably different and his findings support the hypothesis that basic development of Spanish syntax 
is stable for all Spanish-speaking groups.

The DASG utilizes a language analysis method similar to the Developmental Sentence Scoring (DSS) procedure in English developed by Lee and Canter (1971). The names of the grammatical categories, the method of grouping structures, and the statistical procedures were borrowed from the DSS. The DASG is not a translation of the DSS but "was developed taking into account present knowledge of Spanish language acquisition" (Toronto, 1976).

The DASG evaluates developmental syntactic hierarchies of six grammatical categories from a sample of fifty sentences obtained from a child's speech in conversation with an adult: 1) indefinite pronouns and noun modifiers; 2) personal pronouns; 3) primary verbs; 4) secondary verbs; 5) conjunctions; and 6) interrogative words. Other syntactic features, i.e., possessives, plurals, and negatives, are partially taken into account by their inclusion within each of the above categories. The six categories are employed in the procedure because of their apparent developmental qualities as shown in previous studies by Kernan and Blount (1966), Gonzalez (1970), and Toronto (1972).

The DASG evaluates fifty sentences which must be consecutive, complete, and nonecholalic utterances. The sentences are scored according to a developmental weighting system and, the individual scores from each sentence are added together and divided by fifty, or by the number of sentences in the corpus if less than fifty. The result is the Average Sentence Score (AS) which, when compared to the DASG norms, can be used as an estimate of a child's overall grammatical proficiency in spontaneous speech (Toronto, 1976).

Several limitations of the procedure are pointed out by its 
author: 1) The DASG does not provide information for all the developmental syntactic categories of Spanish; 2) subjects of the study were Mexican and Puerto Rican children from the Chicago area; 3 ) the examiner is required to have a thorough knowledge of Spanish grammar to accurately score the speech sample; and 4) it is a time-consuming procedure. Toronto (1976) states:

In spite of these Iimitations the DASG provides a long-needed device which indicates deviant syntactic development in Spanish-speaking children and provides a hypothetical model for sequence of learning syntactic items.

In support, Linares-Orana and Sanders (1977) reported the DASG was demonstrated to be a procedure sensitive to differences in the functioning of similar groups, and that the measure could be usefully employed in research to compare subjects on a linguistic basis.

The review of the available literature of Spanish language acquisition by children demonstrates the need for research in many areas. One of the areas in which research is non-existent, both in the Hispanic countries and in the United States, is in the eliciting of a language sample and the variables affecting the results of this sample in Spanish-speaking children. 
CHAPTER III

METHODS AND PROCEDURES

\section{Subjects}

Twelve low-socioeconomic, normally developing, migrant Spanishspeaking children were chosen to participate in this investigation. The subjects ranged in age from three years, one month to six years, nine months. The subjects, selected by the teachers and the speechlanguage pathologist currently serving the Woodburn Children's Center, met the following criteria in order to participate in the study: 1) normal intelligence according to academic and social behaviors observed by the teacher; 2) normal language, speech, and hearing behaviors as suggested by informal observation; and 3) Spanish as the dominant language spoken at home.

A parental permission form for including the child in the study was signed by the mothers of the subjects and the investigator (see Appendix A).

\section{Socioeconomic Status (SES)}

The Census Bureau, the Labor and Industries Bureau of Oregon at Portland and Salem, the Agriculture Department of Oregon, the Children Services Division (Marion County), the Chamber of Commerce of Woodburn, and the Latin American Association of Woodburn were consulted in order to determine officially the SES for the migrant farm working population of this study. None of these agencies had a statement 
regarding SES and migrant populations, and descriptive information on SES is, therefore, presented on the subjects involved in the study. Housing. The homes in which the subjects lived were all old and in need of reparation. Only three of the families lived in individual houses; the rest lived in apartments which were usually in old, large houses transformed into "apartment buildings." Conditions in both houses and apartments were generally poor and overcrowded. In ten of the cases more than one family (relatives who came from Mexico and California for the strawberry and cucumber seasons) occupied the same dwelling area. In nine of the cases the dwelling area consisted of a smal1 kitchen-dining room and a bedroom-living room. The bathrooms were shared by all the families of the "apartment buildings." In only one case the home appeared dirty and disorderly as compared with the rest.

Education. Information on education was obtained when conversing with the families. Only five of the mothers and three of the fathers completed elementary school (VI grade). One of the mothers completed three years of high school and had training in nursing. of the parents were able to read, although reading level was not determined.

Income. The monthly family income could not be exactly determined due to the source and amount of income variation day by day. It was estimated, in conversation with the families, that $\$ 30$ may be considered the daily mean income during the harvest depending upon the weather and the amount of strawberries or cucumber boxes picked by the members of the family.

It may be concluded from the above description that the subjects 
in this investigation came from poor families, and if classified, would be considered lower SES.

\section{Examiners}

The Spanish-speaking mothers and this Spanish-speaking investigator were the examiners. The mothers were given the following oral and written instructions in Spanish (see Appendix $C$ ) on how to elicit verbal responses from the child:

1. Find a place in your house where you and your child can freely talk for thirty minutes.

2. Sit on the floor or at a table, wherever you and your child feel more comfortable.

3. Talk to your child about the things he does/did at school, about his/her friends, a favorite program in TV, places he/she likes to go, or things he/she likes to play with.

4. Utilize toys and/or pictures. Remember what is important is that the child TALKS, TALKS, TALKS. Feel free to get your child to talk by any means that you choose to use for we want to obtain the best and greatest amount of talking from your child.

Do you have any questions about what you are to do with your child?

A consent form to participate as an examiner in the investigation was signed by the mother and the investigator (see Appendix B).

\section{Instrumentation}

The language samples were recorded utilizing a reel-to-reel Sony tape recorder model TC-104 and a Sony dynamic microphone model MTL F-96. All samples were recorded at a speed of $4.8 \mathrm{~cm} / \mathrm{sec}$. Analysis of the gathered language samples was based on the 
1976). This technique was designed to provide a quantitative measure of syntactic development in spontaneous speech of Spanish-speaking children. Six grammatical-form categories are given developmentally weighted scores and include indefinite pronouns and noun modifiers; personal pronouns; primary verbs; secondary verbs; conjunctions; and interrogative words (see Appendix D).

DASG's scoring procedures are based on a corpus of the last fifty spontaneous, complete, consecutive, intelligible, different, and nonecholalic sentences in a given language sample. When all the sentences have been scored, the individual scores for each sentence are added together and divided by fifty or by the number of sentences in the corpus if less than fifty. This provides a mean sentence score which is referred to as the Average Sentence Score (AS). The AS, when compared to the DASG norms, can be used as an estimate of a child's overall grammatical proficiency in spontaneous speech (Toronto, 1976).

\section{Procedures}

Language Sample Collection

It has been reported consistently in the literature that lowsocioeconomic level Spanish-speaking children living in the United States are reluctant to talk with those adults they consider strangers to their communities or "barrios." Therefore, seven weeks prior to eliciting the language samples, once a week the investigator spent ninety minutes talking, listening, and playing with the children in the classroom and in the Center's back yard.

All language samples were elicited in Spanish. For the sample collection procedure, the subjects were divided into two groups of six 
children each based upon the availability of the mothers to perform the examination. Group I children were first examined by the investigator in the clinic and secondly by the mother in the home. Group II children were first examined by the mother in the home and secondly by the investigator in the clinic. This counterbalancing strategy was devised to control for any order effect in the child's behavior. A minimum of one week and a maximum of three elapsed between the home and the clinic situations.

\section{Sample Collection at Home}

In the home the samples were gathered usually in the living/ sleeping quarters or kitchen. Each mother was instructed to spend thirty minutes talking with her child in order to elicit as much speech as possible. Only three mothers, however, were able to complete the thirty-minute task and, therefore, the task was revised to accept fifteen minutes as the amount of time spent by the mothers when conversing with their children. The tape recorder and the microphone were set up by the investigator prior to the sample collection. The investigator then left the room so the mother could comfortably elicit the sample.

Sample Collection at the Clinic

The room utilized by the speech and language clinic in the Woodburn Children's Center is shared with the Center's nurse. One childsize table, three child-size chairs, an adult-size desk and chair, a medicine cabinet, and a weighing scale comprise the furniture. The room is a $2 \mathrm{~m} \times 2 \mathrm{~m}$ room located in the administrative area of the Center. In gathering the language samples in the clinic, toys, pictures, 
books, and informal conversation were used to stimulate verbalizations. Open-ended questions, "Tell me more about it," and comments about the child's ideas were also used by the investigator to elicit further verbalizations from the child. In terms of time, thirtyminute periods were completed with each subject but, in order to compare the clinic and home settings, DASG analysis of each clinic sample was conducted only on the first fifteen minutes of the elicited corpus.

\section{Data Scoring and Analysis}

The investigator was trained in transcription by an assistant professor in the Portland State University Speech and Hearing Sciences Program who has had ten years' experience in language sample transcription .

Each tape recording was transcribed into a typed transcript and tabulated for the Developmental Assessment of Spanish Grammar (DASG) (Toronto, 1972, 1976). In selecting the consecutive, complete, nonecholalic sentences for grammatical analysis the procedure described by Toronto (1976) was utilized. This procedure is sumarized as follows :

1. The DASG requires a corpus of fifty spontaneous, complete, consecutive, intelligible, different, and nonecholalic sentences. Lee (1974) recommends, however, if less than fifty utterances are elicited, the analysis may be conducted but the results should be considered tentative.

2. Independent clauses are counted as sentences when found in the midst of fragments. Dependent clauses are not counted as complete sentences.

3. Utterances which are incomplete or unintelligible are omitted from the sample and consecutive counting resumes from the last complete sentence. 
4. Any sentence that is repeated should be scored only once.

5. If a child's utterance is unintelligible because of low vocal intensity, dysfluency, or articulation errors, it is omitted from the corpus. Care should be taken not to penalize a child for articulation errors.

6. If a child in attempting to repeat the examiner's utterance changes the sentence in any way, that sentence is included in the corpus.

7. In order for a pronoun to receive points in the Indefinite Pronouns and Noun Modifiers category, it must agree in number with the corresponding verb. A noun modifier must agree in number and gender with the noun it modifies.

8. Personal, reflexive, and relative pronouns are included in the category of Personal Pronouns. Person, number, gender, and case must be correctly used in a sentence in order for a pronoun to receive credit.

9. In scoring Primary Verbs, a score of one is given to present tense singular conjugations for first, second, and third persons. Any plural, preterit tense, or imperative verb constructions receive a score of two. Use of copulas receives a score of three, along with the use of the imperfect past tense and use of the subjunctive mood. The remainder of the verb hierarchy contains more complex verb constructions which are given higher scores (see Appendix D).

10. In the category of Secondary Verbs, infinitives such as those derived from the verbs "ir," "querer," "saber," "dejar," and "gustar," receive two points. Present participles are given a score of three if they occur after any verb other than "estar." Passive complements and gerunds are the most complex secondary verbs in Spanish and receive scores of seven and eight, respectively.

11. In scoring the category of Conjunctions the following rules must be followed. Sentences which begin with conjunctions are counted as complete sentences, but the conjunctions are not scored. Only one "y" conjunction per sentence is allowed when it connects two independent clauses. 
12. Interrogative words are scored when used in a question and are simply given their respective points when they occur.

In order to make the clinic and home settings comparable in terms of time, DASG analysis was conducted in the actual number of sentences obtained in fifteen-minute samples; therefore, some samples were less than the required fifty complete utterances. Lee (1974) observes, however, even in this case the analysis may be conducted but the results should be considered tentative.

Comparison of DASG total scores and DASG individual category scores were made between the home and the clinic samples. Mean scores were determined for the subjects' performances in the two different settings with two different examiners. Differences between the means of the different results were analyzed utilizing a t-test. In addition, t-test analysis was conducted to determine the significance level of DASG scores when compared by age and sex in the clinic and in the home, and by order of examination. 
CHAPTER IV

\section{RESULTS AND DISCUSSION}

\section{$\underline{\text { Resu1ts }}$}

The purpose of this study was to compare the quality of spontaneous language samples elicited from Spanish-speaking children by their mothers in the home and by this investigator in the clinical setting. The essential question to be answered was: Are there any significant differences, as measured by the Developmental Assessment of Spanish Grammar (DASG), in language samples elicited from normal Spanish-speaking children by the mothers in the home and a Spanishspeaking clinician in the clinical setting? A11 comparisons were made in the actual number of sentences obtained in 15-minute samples; therefore, only 11 of the total amount of 24 samples met the 50 complete utterances required by the DASG. Comparison of the DASG scores (Table I) revealed a mean DASG score of 4.89 for the samples elicited by the clinician (Condition A) and 5.40 for the samples elicited by the mother (Condition B). Results of a two-tailed t-test analysis indicated no statistically significant difference between the two conditions at the .05 level of confidence (Table II).

Comparisons of mean DASG scores for each grammatical category in each setting were conducted (Table III). Mean scores for the Indefinite Pronouns and Noun Modifiers category revealed a mean score of 21.58 in the clinic and 29.08 in the home. Mean scores for the 
TABLE I

DASG SCORES OBTAINED IN THE CLINIC AND IN THE HOME

\begin{tabular}{cllcc}
\hline Subjects & Age & Sex & $\begin{array}{c}\text { DASG Score } \\
\text { in Clinic } \\
\text { Condition A }\end{array}$ & $\begin{array}{c}\frac{\text { DASG Score }}{\text { in Home }} \\
\text { Condition B }\end{array}$ \\
\hline 1 & 5.2 & F & 4.60 & 4.39 \\
2 & 5.10 & F & 3.66 & 4.31 \\
3 & 3.2 & F & 3.32 & 5.34 \\
4 & 3.1 & M & 3.72 & 3.36 \\
5 & 4.8 & F & 4.92 & 6.92 \\
6 & 5.4 & F & 5.42 & 6.06 \\
7 & 5.10 & M & 6.76 & 5.91 \\
8 & 3.2 & M & 3.76 & 4.78 \\
9 & 4.1 & M & 3.00 & 4.50 \\
10 & 5.8 & F & 3.46 & 5.50 \\
11 & 6.9 & M & 9.06 & 6.70 \\
12 & 6.8 & M & 7.03 & 7.08 \\
& Mean &. & 4.89 & 5.40 \\
\hline
\end{tabular}

Personal Pronouns category revealed a mean score of 53.33 in the clinic and 65.33 in the home. Mean scores for the Primary Verbs category revealed a mean score of 74.33 in the clinic and 75.33 in the home. Mean scores for the Secondary Verbs category revealed a mean score of 16.00 in the clinic and 16.75 in the home. Mean scores for the Conjunctions category revealed a mean score of 39.50 in the clinic and 
TABLE II

COMPARISON OF MEAN DASG SCORES OBTAINED IN

THE CLINIC AND IN THE HOME

\begin{tabular}{lllll}
\hline Condition & Mean & S.D. & df & $\underline{t}$ \\
\hline $\begin{array}{l}\text { Subject-Investigator } \\
\text { in the clinic } \\
(\text { Condition A) }\end{array}$ & 4.89 & 1.86 & & \\
$\begin{array}{l}\text { Subject-Mother } \\
\text { in the home } \\
\text { (Condition B) }\end{array}$ & 5.40 & 1.17 & & 1.32 \\
\hline
\end{tabular}

34.16 in the home. Mean scores for the Interrogative Words category revealed a mean score of 4.08 in the clinic and 3.91 in the home. The results of a two-tailed t-test for each individual category in the clinic and in the home revealed no statistically significant differences for any category at the .05 level of confidence.

An analysis of DASG scores obtained by the four different age groups of children in the clinic and in the home was performed (Table IV). Children whose age ranged from 3.1 to 3.2 with a mean age of 3.1 (Group I) revealed a mean DASG score of 3.60 in the clinic and 4.49 in the home. Children whose age ranged from 4.1 to 4.8 with a mean age of 4.4 (Group II) revealed a mean DASG score of 3.96 in the clinic and 5.71 in the home. Children whose age ranged from 5.2 to 5.10 with a mean age of 5.2 (Group III) revealed a mean DASG score of 4.78 in the clinic and 5.23 in the home. Children whose age ranged from 6.8 to 6.9 with a mean age of 6.7 (Group IV) revealed a mean DASG score of 


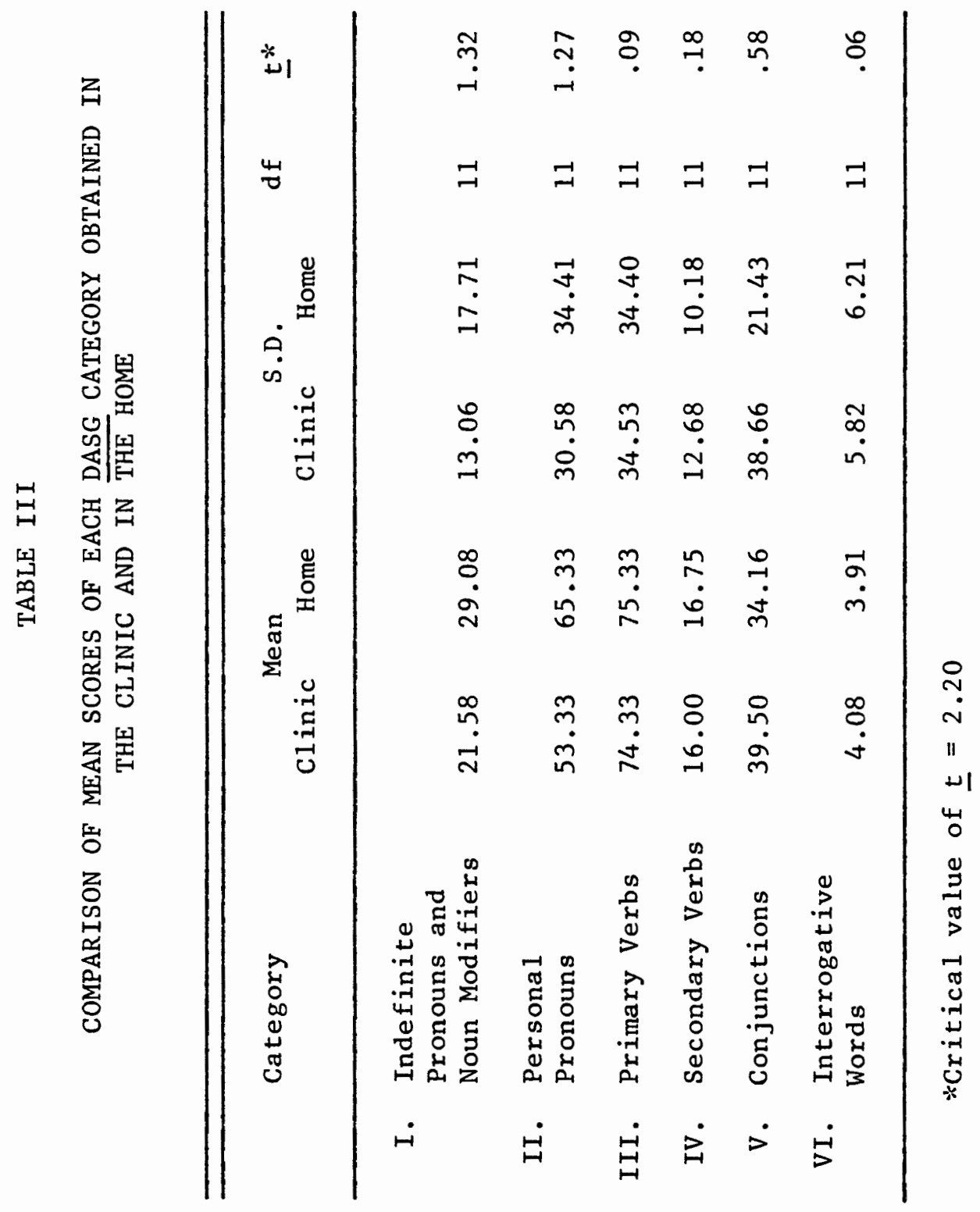




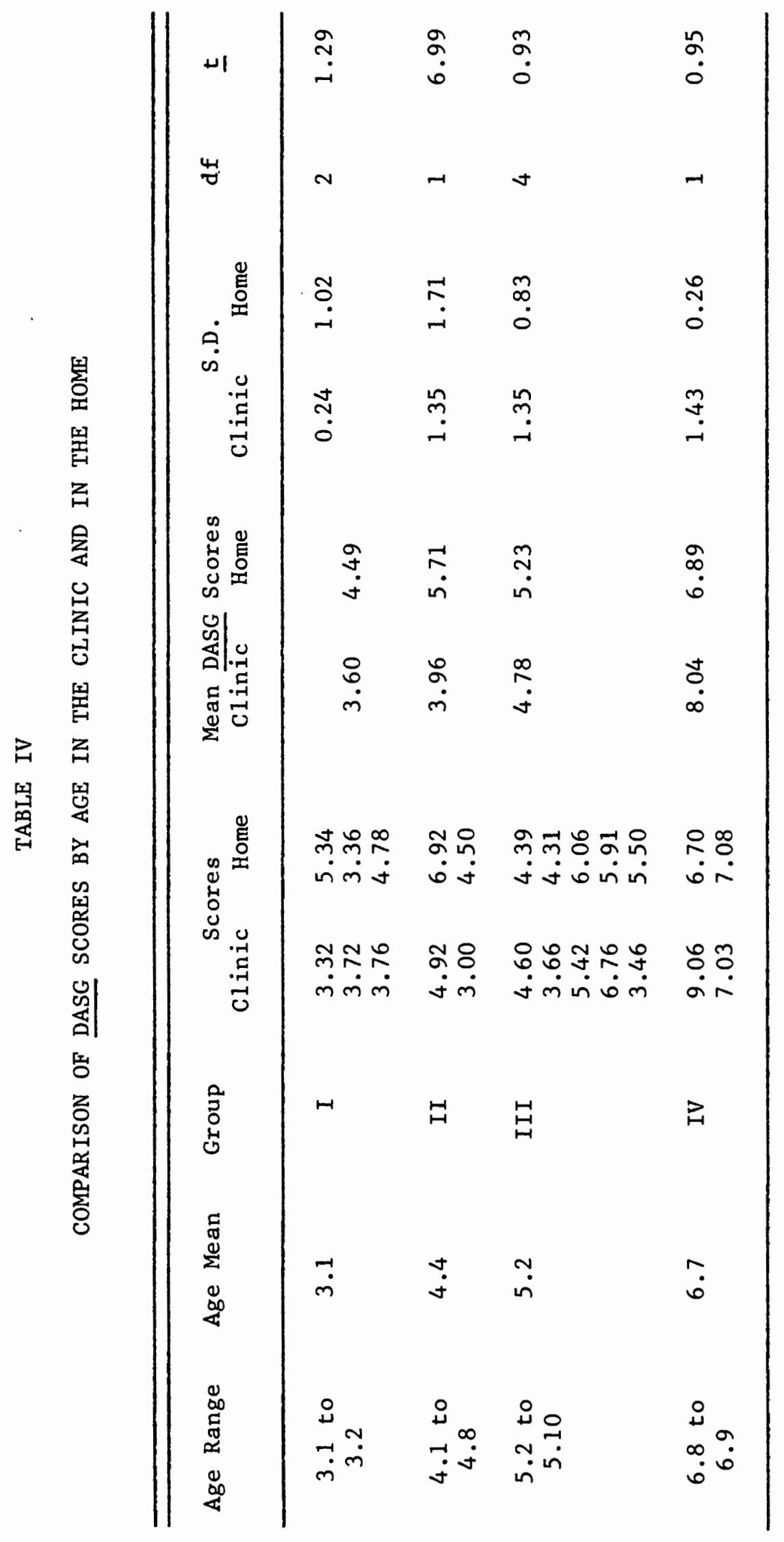


8.04 in the clinic and 6.89 in the home. The results of a two-tailed t-test for each individual age group in the clinic and in the home revealed no statistically significant difference for any group at the .05 level of confidence.

Further analysis of DASG scores by the above age groups in the clinic and in the home was conducted. Comparisons were made between Groups I and II; II and III; and III and IV (Table V). In the clinic, Groups I, II, III, and IV obtained, respectively, a mean DASG score of $3.60,3.96,4.78$, and 8.04 . Results of t-test analysis indicated no statistically significant differences at the .05 level of confidence when Groups I and II, and II and III, were compared. Results of $\underline{t}$-test analysis indicated a higher level of syntactic language development which was significant at .05 level of confidence for Group IV when compared to Group III. In the home, Groups I, II, III, and IV obtained, respectively, a mean DASG score of $4.49,5.71,5.23$, and 6.89. Results of t-test analysis indicated no statistically significant differences at the .05 level of confidence when Groups I and II, and II and III, were compared. Results of t-test analysis indicated a higher level of syntactic language development which was significant at .05 level of confidence for Group IV when compared to Group III. Examination of Table III reveals that: 1) Home sample's yielded slightly higher scores than clinic samples; and 2) independent of the settings, as the age of the children increased so did the mean DASG scores.

Comparison of mean DASG scores by sex in the clinic and in the home (Table VI) revealed a mean DASG score of 4.23 for the female group in the clinic (Group FC) and 5.42 for the female group in the home (Group FH). Results of t-test analysis indicated a higher level 


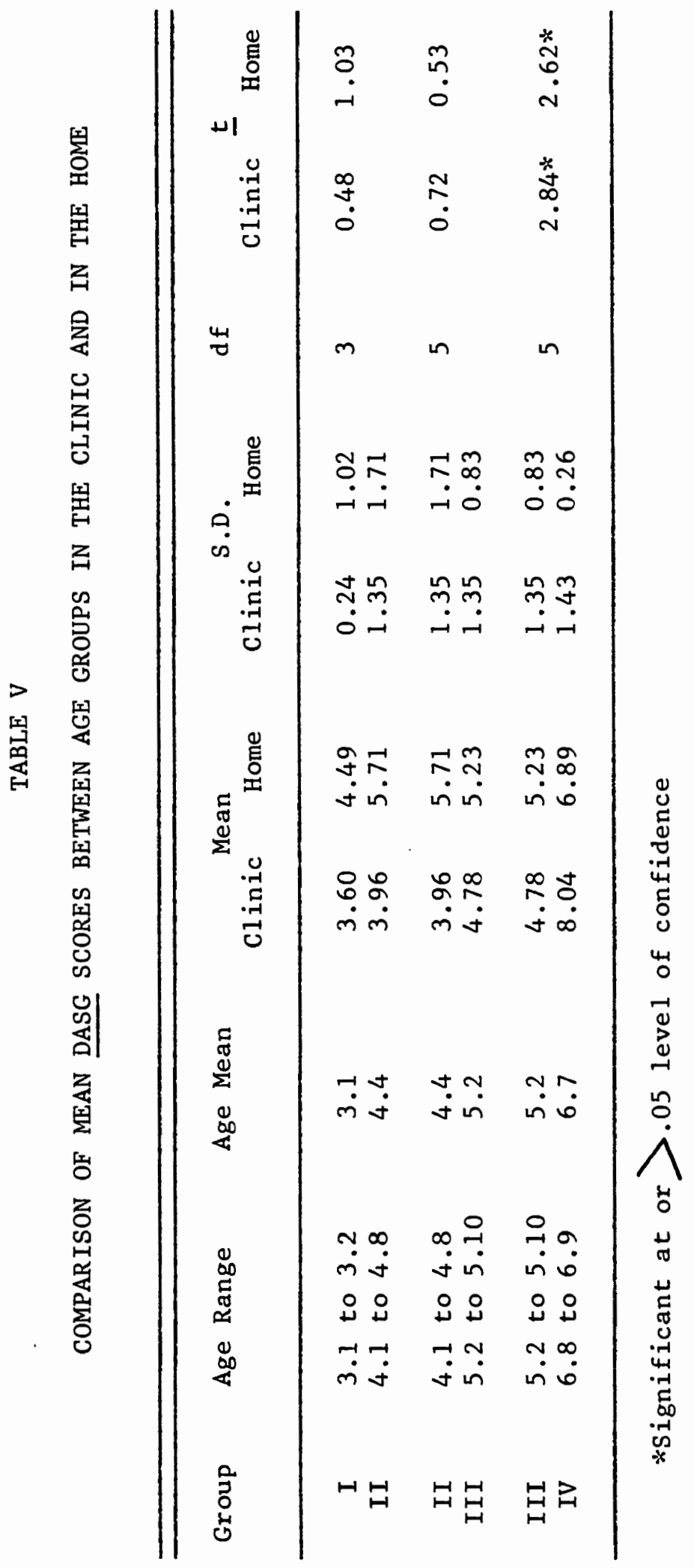


TABLE VI

COMPARISON OF MEAN DASG SCORES BY SEX IN THE CLINIC AND IN THE HOME

\begin{tabular}{|c|c|c|c|c|c|c|}
\hline \multirow{2}{*}{ Group } & \multicolumn{2}{|c|}{ Mean } & \multicolumn{2}{|c|}{ S.D. } & \multirow{2}{*}{$d f$} & \multirow{2}{*}{$\underline{t}$} \\
\hline & Clinic & Home & Clinic & Home & & \\
\hline $\begin{array}{l}\text { Female Clinic } \\
(\mathrm{FC})\end{array}$ & 4.23 & & 0.86 & & & \\
\hline $\begin{array}{l}\text { Female Home } \\
(\mathrm{FH})\end{array}$ & & 5.42 & & 0.99 & 5 & $3.03 *$ \\
\hline $\begin{array}{l}\text { Male Clinic } \\
\text { (MC) }\end{array}$ & 5.55 & & 2.40 & & & \\
\hline $\begin{array}{l}\text { Male Home } \\
\text { (MH) }\end{array}$ & & 5.38 & & 1.42 & 5 & 0.29 \\
\hline
\end{tabular}

$\because$ Significant at or $>.05$ level of confidence

of syntactic language development as measured by the DASG for the female group in the home, which was significant at the .05 level of confidence. Mean DASG score was 5.55 for the male group in the clinic (Group MC) and 5.38 for the male group in the home (Group MH). Results of $\underline{t}$-test analysis indicated no significant difference between the male group in the clinic and the male group in the home at .05 level of confidence.

Further comparison of the above sex groups was conducted in the clinic and in the home (Table VII). The female group in the clinic (Group FC) was compared to the male group in the clinic (Group MC). The mean DASG score was 4.23 for Group FC and 5.55 for Group MC. Results of the $\underline{t}$-test analysis indicated no significant difference for 
Groups FC and MC at the .05 level of confidence. In another comparison the female group in the home (Group FH) was compared to the male group in the home (Group MH). The mean DASG score was 5.42 for Group $\mathrm{FH}$ and 5.38 for Group MH. Results of the t-test analysis indicated no significant difference for Groups $\mathrm{FH}$ and $\mathrm{MH}$ at .05 level of confidence. Examination of Table $\mathrm{V}$ reveals that: 1) Females obtained a higher mean DASG score in the home than in the clinic; and 2) males obtained a higher mean DASG score in the clinic than in the home.

\section{TABLE VII}

COMPARISON OF MEAN DASG SCORES BETWEEN SEX GROUPS IN THE CL $\overline{\text { INIC }}$ AND IN THE HOME

\begin{tabular}{|c|c|c|c|c|c|c|}
\hline \multirow[t]{2}{*}{ Group } & \multicolumn{2}{|c|}{ Mean } & \multicolumn{2}{|c|}{ S.D. } & \multirow[t]{2}{*}{$d f$} & \multirow[t]{2}{*}{$\underline{t}$} \\
\hline & Clinic & Home & Clinic & Home & & \\
\hline FC (Female clinic) & 4.23 & & 0.86 & & 10 & 1.26 \\
\hline MC (Male clinic) & 5.55 & & 2.40 & & & \\
\hline $\mathrm{FH}$ (Female home) & & 5.42 & & 0.99 & 10 & 0.04 \\
\hline $\mathrm{MH}$ (Male home) & & 5.38 & & 1.42 & & \\
\hline
\end{tabular}

Analysis of DASG scores according to order of examination is displayed in Table VIII. The mean DASG score was 5.19 for the first examination and 5.10 for the second examination. Results of the $\underline{t}$-test analysis indicated no significant differences between examinations at the .05 level of confidence. 
TABLE VIII

COMPARISON OF MEAN DASG SCORE OBTAINED BY

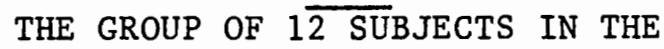

FIRST AND THE SECOND

EXAMINATIONS

\begin{tabular}{ccccc}
\hline Examination & Mean & S.D. & df & $t$ \\
\hline I & 5.19 & 1.65 & & \\
II & 5.10 & 1.48 & & 0.22 \\
\hline
\end{tabular}

\section{Discussion}

The primary purpose of the study was to compare the quality of spontaneous language samples elicited from Spanish-speaking children by the mothers in the home and by the investigator in the clinic.

The essential question sought to determine if the comparison of language samples elicited in the home by the mothers, and the language samples elicited in the clinic by the investigator, yielded significant differences in syntactical language development as measured by the Developmental Assessment of Spanish Grammar (DASG). As shown in Table II, results indicated no statistically significant difference between the DASG scores of the samples elicited in the clinic (Condition A) and the samples elicited in the home (Condition B) (Figure 1). Examination of Figure 2 reveals that in eight cases the DASG scores were higher for the home than the clinic, and four of these scores were noticeably higher than those achieved in the clinic. It also is observed that two of the clinic samples were noticeably higher than 

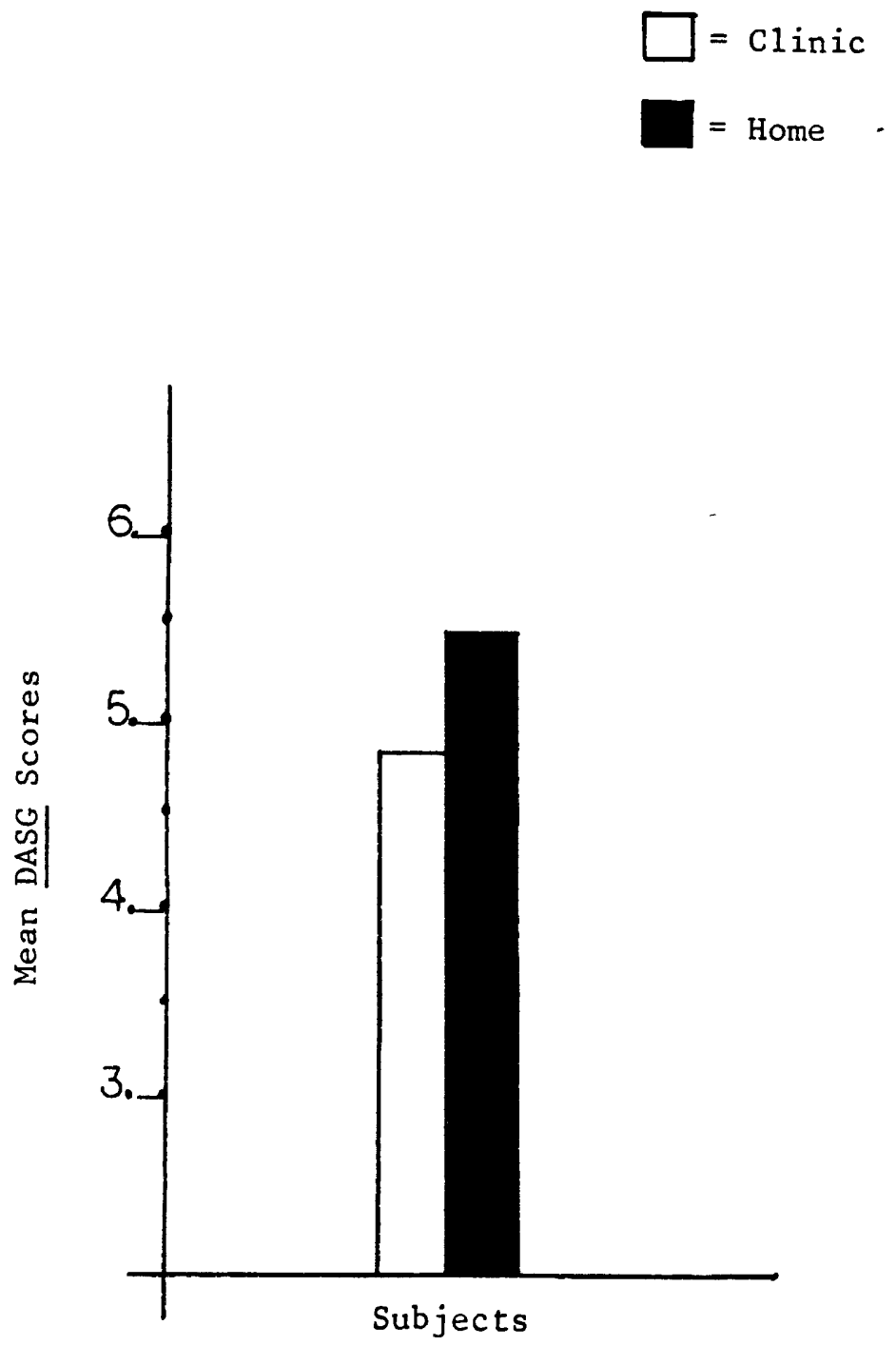

Figure 1. Comparison of DASG scores by the group of 12 subjects in the clinic and in the home. 


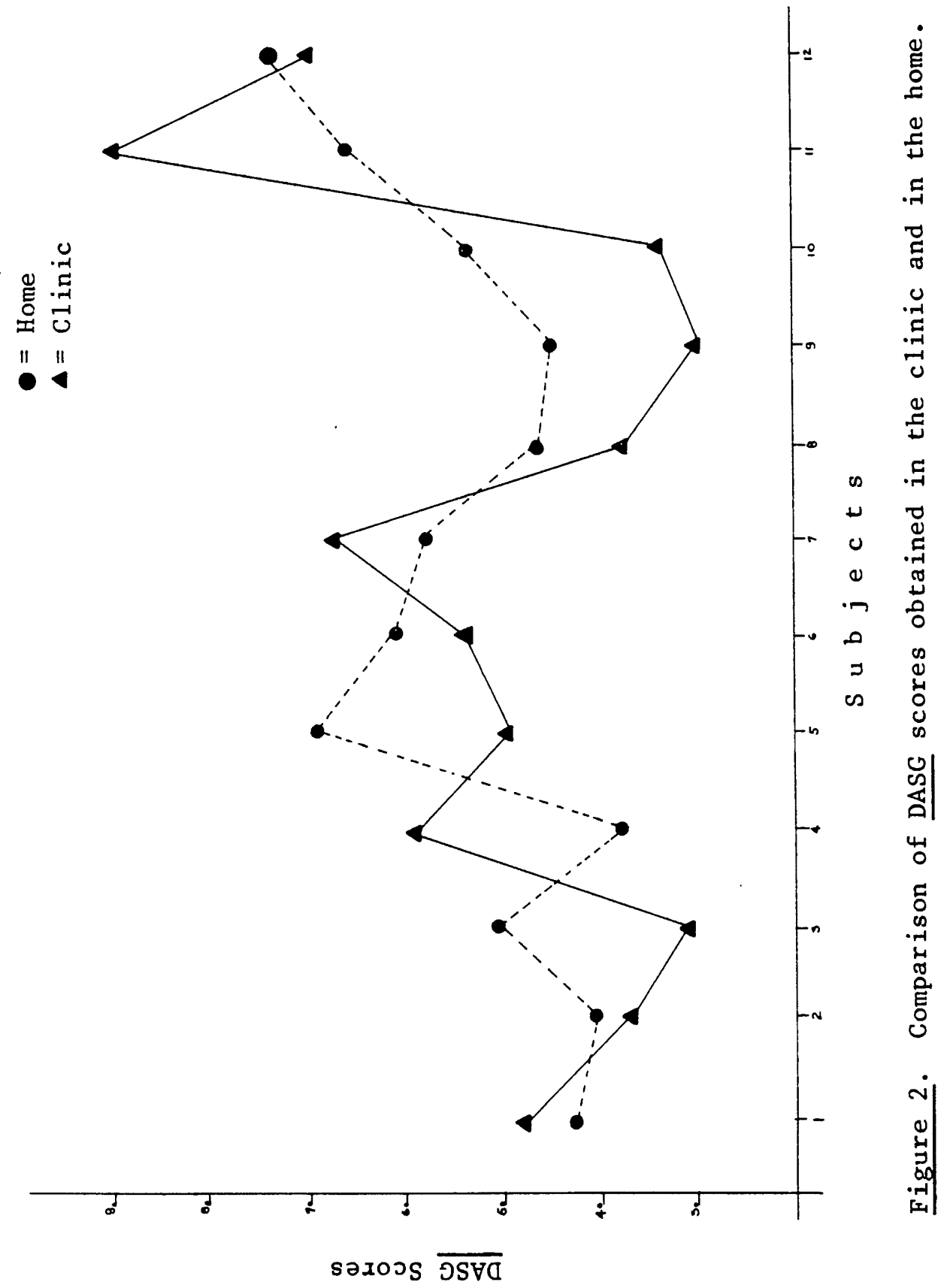


those obtained in the home, one of them being the highest of all the scores (subject 11) for both settings.

In spite of the differences in language and type of population investigated, results of this study concur with those of scott et al. (1978), Olswang and Carpenter (1978), and Kramer et al. (1979), whose subjects were English-speaking children. Results from these studies and the present study indicated no statistically significant differences between clinic and home language samples but, there was a trend toward a small difference in the use of syntactic structures, with the more complex syntactic structures used more often in the home. One factor accounting for this difference might be that the mother has a long-term relationship with her child whereas this investigator met the subjects seven weeks prior to elicitation of the samples, and spent ninety minutes once a week getting acquainted with the subjects. Events in the home provide the child with past experiences he and his mother can talk about. The clinician is constrained to the clinic materials and to the ability and knowledge to elicit the best speech from the child. While references in the clinic are made only to ongoing events, the mother and the child may talk about events of the past or near future which may elicit the use of more complex syntactical forms and, therefore, a better DASG score may result in the home sample. Further analysis of DASG scores for each grammatical category confirms the above results (Table III). Examination of Figure 3 reveals that in fact there was an observable difference for the use in the home of more complex Indefinite Pronouns and Noun Modifiers, and, Personal Pronouns (Categories I and II); and a slight difference for the use in the home of more complex Primary and Secondary Verbs 


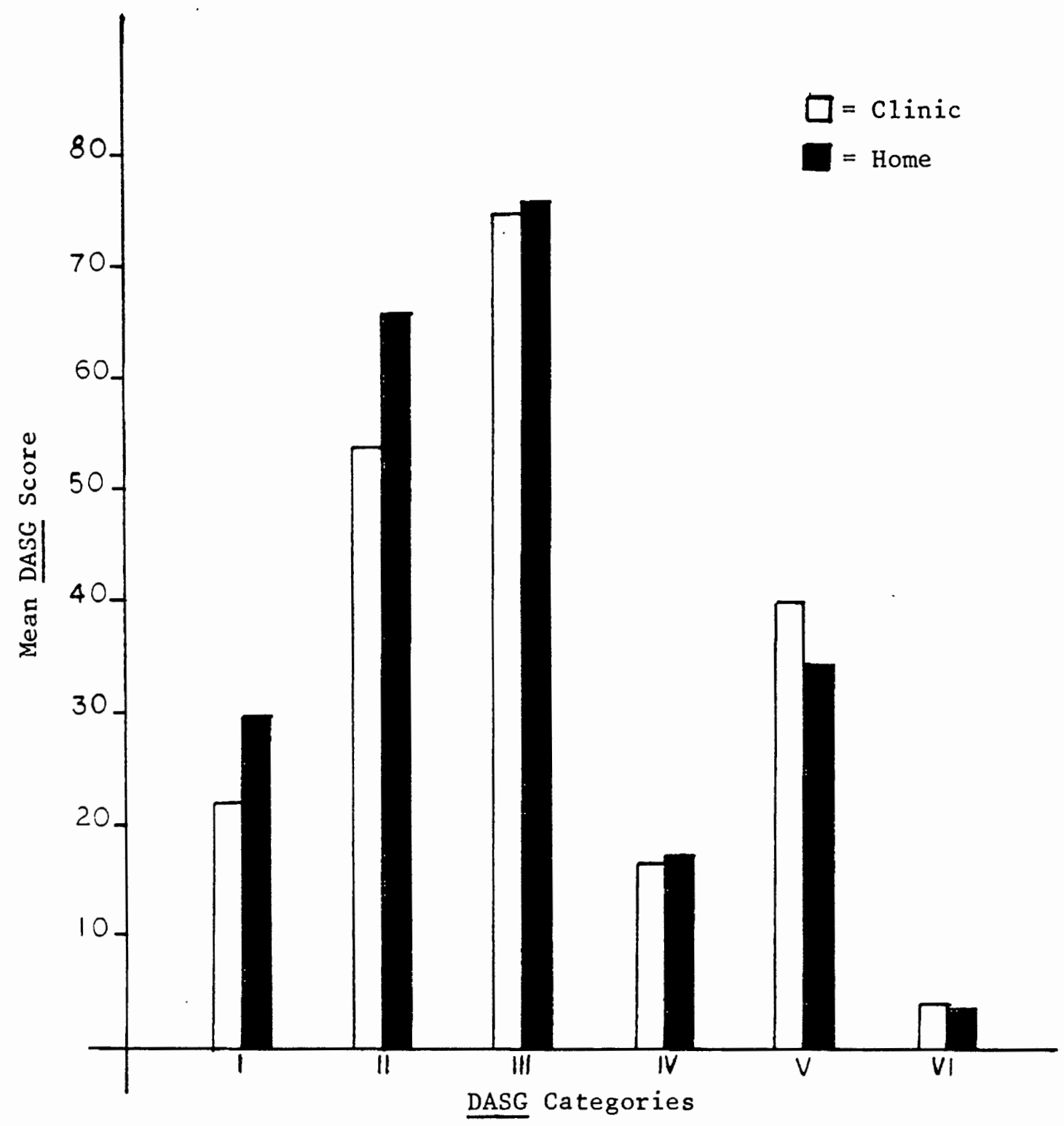

Figure 3 . Comparison of mean DASG score for each category in the clinic and in the home. 
(Categories III and IV). Of all the six categories composing the DASG, the above four were found to be highly correlated and to be the primary indicators of a subject's syntactic language development (Toronto, 1972).

In addition to the mother-child long-term relationship factor, another factor to be considered as affecting the results of the study is the "barrio" effect. Although in this particular case the investigator had become acquainted with the subjects over a short period of time, the "barrio" sociological factor still seemed to interfere with the interaction of investigator-subject in most of the cases.

When considering the DASG score for the four age groups of subjects (Table IV), it may be noted there were no statistically significant differences for any of the groups. The small sample size for each group may be considered to be a factor accounting for the lack of significance (Figure 4). When further comparisons were made across groups in the home and in the clinic (Table V), Group IV (the oldest group) demonstrated a higher level of syntactic language development as compared to Group III (age range 5.2 to 5.10). The above finding supports the hypothesis found in the available literature regarding language development: As the child grows older, there is a concomitant increase in knowledge of the syntactic structures of the language and, therefore, higher scores are obtained (Toronto, 1972).

Differences of mean DASG scores by sex also were analyzed (Table VI). A comparison was first made intra-group. In other words, each female served as her own control in the clinic and in the home; and, each male served as his own control in the clinic and in the home. Results of this comparison demonstrated a higher level of syntactic 


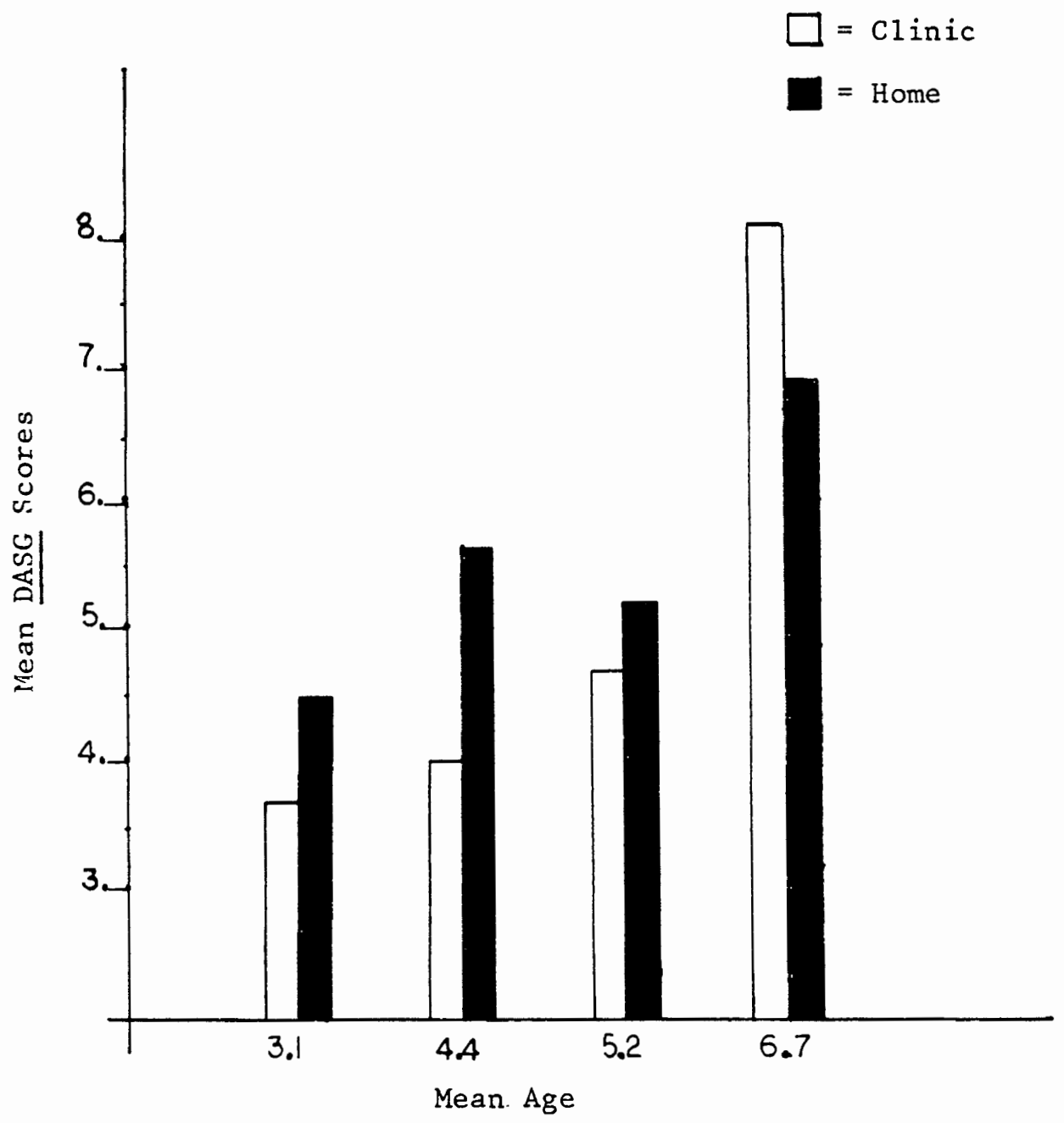

Figure 4. Comparison of mean DASG scores by age in the clinic and in the home. 
language development for the female group in the home. As a contrast, the comparison of the male group for both settings did not show significant differences between settings. Personality might be a factor accounting for differences obtained by the female group in the home as compared to the same group in the clinic. Four out of six females were observed to be shy and slightly reserved when talking to strangers (including the investigator). A cultural factor also might be considered: Women are expected to be reserved in the Latin culture, especially when talking to a non-familiar person. It is possible, therefore, that the female subjects felt more comfortable talking to their mothers in a familiar setting. As it is observed in Table $V$, the mean DASG scores for the male group did not show statistically significant differences between settings. Three factors may account for such a result: The two oldest subjects of the total sample size were males, and as it was explained earlier, the older the subject, the higher the syntactic language development and the higher the score. In addition, the extremely high score obtained in the clinic by one of these two oldest subjects, subject 11 , may have skewed the male clinic group scores upward. An additional factor accounting for the lack of significance may be the small sample size.

Further comparisons across sex groups showed no statistically significant differences between the male and female groups in the clinic or the home (Table VII). This is graphically displayed in Figure 5. Although the small sample size for each sex might account for the lack of significant differences on mean DASG scores, the above results concur with findings of Kernan and Blount (1966) and Toronto (1972, 1976), who found no significant differences between the male 

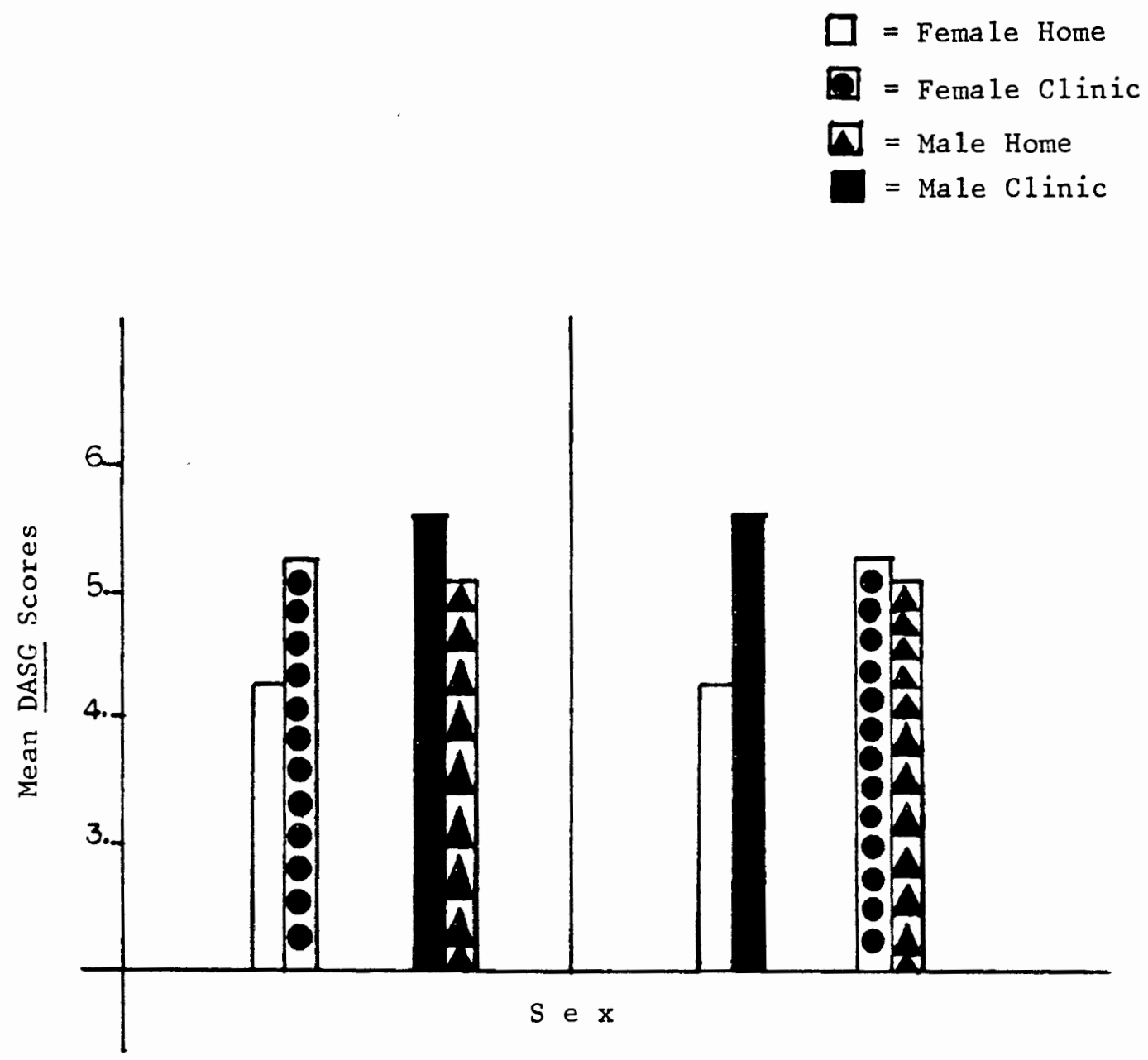

Figure 5. Comparison of mean DASG scores by sex in the clinic and in the home. 
and female groups in their respective studies with lower SES Mexican subjects. The few available investigations found in the current literature and conducted with Spanish-speaking subjects do not offer enough information to hypothesize any reason for the lack of difference between the male and female groups.

Analysis of DASG scores by order of examination revealed no statistically significant differences between the first and the second examinations. It may be seen in Figure 6 that six subjects obtained higher scores in the first examination, five subjects obtained higher scores in the second examination, and one subject obtained essentially the same results, the second examination being only slightly higher than the first one. When considering the interaction between order of examination and examiner, it also is observed that eight of the higher results, four on the first examination and four on the second examination, were obtained in language samples elicited by mothers. Two of the first examinations conducted by the investigator, however, obtained the highest DASG scores of all the samples. The mean difference between first and second examinations was 0.09 in favor of the first examination, while there was a difference of 0.50 in favor of the investigator when considering examiner difference for the first examination. This last result, however, should be interpreted with caution. The subjects who obtained the highest results were, once again, the oldest of the group. Subject 11 , particularly, obtained the highest result, which apparently skewed upward the results obtained by the investigator in the first examination.

When results of the DASG scores were compared to the DASG norms (Toronto, 1972, 1976) (Table IX), only eight of the subjects met the 


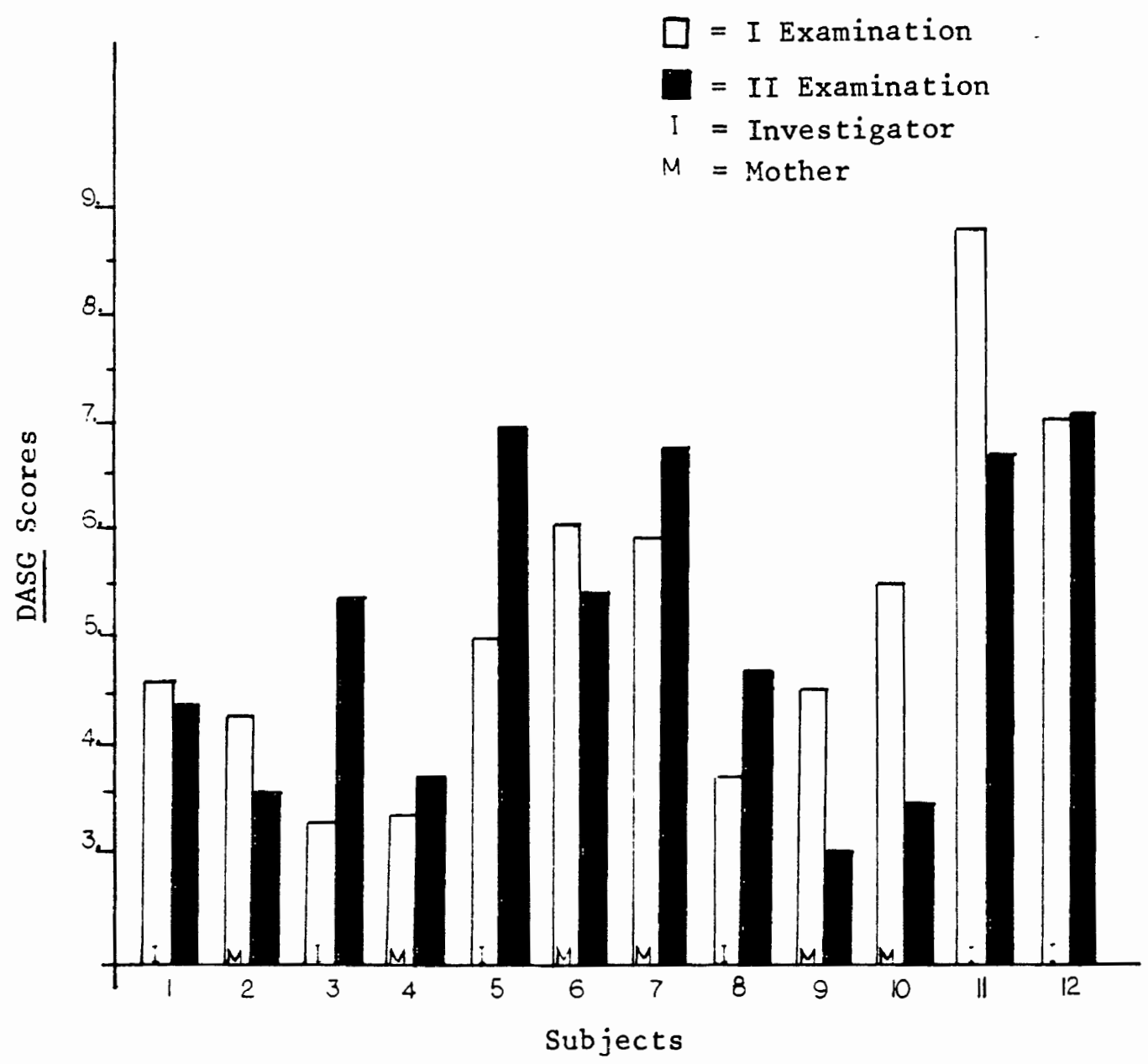

Figure 6. Comparison of the DASG score of each subject between the first and the second examinations. 
TABLE IX

COMPARISON BETWEEN DASG NORMS AND DASG SCORES OBTAINED IN THE CLINIC AND IN THE HOME

\begin{tabular}{|c|c|c|c|c|c|}
\hline $\begin{array}{c}\text { Age } \\
\text { (Years) }\end{array}$ & $\frac{\text { DASG }}{\text { Mean }}$ & $\begin{array}{l}\text { Norms } \\
\text { S.D. }\end{array}$ & $\begin{array}{c}\text { Scores obt } \\
\text { Age }\end{array}$ & $\begin{array}{l}\text { ined by } \\
\text { CIinic }\end{array}$ & $\begin{array}{c}\text { the Subjects } \\
\text { Home }\end{array}$ \\
\hline 3 & 4.25 & 1.00 & $\begin{array}{l}3.1 \\
3.2 \\
3.2\end{array}$ & $\begin{array}{l}3.72 * \\
3.32 * \\
3.76 *\end{array}$ & $\begin{array}{l}3.36 * \\
5.34 * \\
4.78 *\end{array}$ \\
\hline 4 & 5.56 & 1.10 & $\begin{array}{l}4.1 \\
4.8\end{array}$ & $\begin{array}{l}3.00 \\
4.92 *\end{array}$ & $\begin{array}{l}4.50 \% \\
6.92 \%\end{array}$ \\
\hline 5 & 6.69 & 1.51 & $\begin{array}{l}5.2 \\
5.4 \\
5.8 \\
5.10 \\
5.10\end{array}$ & $\begin{array}{l}4.60 \\
5.42 * \\
3.46 \\
6.76 * \\
3.66\end{array}$ & $\begin{array}{l}4.39 \\
6.06 * \\
5.50 * \\
5.91 * \\
4.31\end{array}$ \\
\hline 6 & 7.64 & 1.65 & $\begin{array}{l}6.8 \\
6.9\end{array}$ & $\begin{array}{l}7.03 * \\
9.06 *\end{array}$ & $\begin{array}{l}7.08 * \\
6.70 *\end{array}$ \\
\hline
\end{tabular}

$*$ Reached the norm for age level

criteria for their respective age in both settings. Home scores for subjects 3 and 8 were 1 SD above the norms for their age. Caution should be taken, however, when considering the validity of their language samples at home. As an exception from the rest of the subjects, the language samples produced by subjects 3 and 8 in the home setting were nullified due to the reluctance of these subjects to talk for more than 9 and 11 minutes, respectively. A third examination was scheduled, the mothers once again were given directions on how to elicit the language sample, and 15-minute samples were recorded for each subject. At that time, some learning effect might have taken place and, therefore, may have influenced the results. 
Subjects 9 and 10 met the norms for the home sample only. The failure of subject 9 to meet the norms for the clinic sample might have been influenced by his behavior during the eliciting procedure. His behavior was characterized by reticence and by other behaviors such as closing his eyes and not answering, hitting the toys, and throwing the pictures. It was later reported to the investigator the subject had developed behavioral problems in the last month which the mother also had observed in the home. Subject 10 is a very shy female who met the investigator only two weeks prior to the elicitation procedure. Her shyness, in addition to some "barrio" effect, therefore, may have precluded a better performance in the clinic.

The remainder of the subjects, subjects 1 and 2 , did not meet the norms for either setting. Subject 1 appears to be a normally developing female whose better results in the clinic and in the home may have been prevented by her shyness in the clinic and the absolute lack of privacy during the home sample. Lack of privacy also may have prevented subject 2 from obtaining a better score in the home sample. In the clinic sample, however, in spite of the perfect degree of privacy and her willingness to talk, subject 2 obtained the lowest score for her age group.

As stated earlier, in only 11 of the total amount of 24 language samples was 50 sentence-based DASG analysis accomplished. This fact deserves further explanation. In the original design of the present study, the mothers and the investigator were expected to spend 30 minutes with the subject in each setting. It was assumed this would allow enough time to collect the 50 sentences. In the clinic setting all the samples were taken within that period of time. Although in 
most of the cases the subjects were reticent at first, they remained on task and 50 sentences were obtained in 11 cases. Subject 9 was the only case in which less than 50 sentences were obtained in the 30minute period. His behavior was characterized by reticence and by other physical manifestations which might have influenced the number of elicited utterances. In the home sample, the subject was less reticent, but the mother did most of the talking in her effort to elicit the most speech from the subject. As opposed to the clinic, in the home setting the 30-minute period of time was met in only 3 of the 12 language samples. As can be observed in Table $\mathrm{X}$, in the clinic the time was the same for all subjects while in the home the period of time ranged from 15 to 30 minutes. Such variety of times in the home

TABLE X

ACTUAL TIME AND AMOUNT OF UTTERANCES BY EACH SUBJECT OBTAINED IN THE CLINIC AND IN THE HOME

\begin{tabular}{ccccc}
\hline Subject & $\begin{array}{c}\text { \# Utterances } \\
\text { in Clinic }\end{array}$ & $\begin{array}{c}\text { Time } \\
\text { (Minutes) }\end{array}$ & $\begin{array}{c}\text { 位 Uterances } \\
\text { in Home }\end{array}$ & $\begin{array}{c}\text { Time } \\
\text { (Minutes) }\end{array}$ \\
\hline 1 & 81 & 30 & 55 & 21 \\
2 & 86 & 30 & 44 & 19 \\
3 & 70 & 30 & 44 & $15 *$ \\
4 & 78 & 30 & 56 & 30 \\
5 & 100 & 30 & 80 & 17 \\
6 & 80 & 30 & 60 & 16 \\
7 & 83 & 30 & 37 & $16 *$ \\
8 & 78 & 30 & 54 & 17 \\
9 & 34 & 30 & 10 & 31 \\
10 & 90 & 30 & 60 & 30 \\
11 & 145 & 30 & 139 & \\
12 & 72 & 30 & 90 & \\
\hline
\end{tabular}

*Results obtained in a third examination 
and the discrepancy between home and clinic times may be caused by two main factors. First, in the clinic room the subjects and the investigator worked in absolute privacy while in the home, privacy was comparable to that in the clinic only for subjects $4,10,11$, and 12 . For the two subjects whose home samples were repeated, the degree of privacy was comparable to that in the clinic in only the repeated third examination. The second factor to be considered is the examiners themselves. While the investigator has had training in eliciting language samples and has the knowledge to maintain the subject on task, the mothers do not. In addition, while the investigator elicited the samples primarily in the morning hours, the mothers elicited their samples in the evening, between $4: 30$ and $6: 30$, after a 12-hour day of work in the fields. A logical conclusion may be that for these farm-working mothers, the time of 30 minutes established for the investigator in the home was an unrealistic goal for them to meet in terms of amount of time. Thirty minutes, however, appeared to be the time needed to elicit 50 scorable sentences in both settings.

As stated earlier, in the clinic all the language samples lasted for 30 minutes while in the home the time ranged from 15 to 30 minutes. Due to this discrepancy and in order to make both settings comparable, the first 15 minutes of the samples obtained on each setting were utilized to carry out the DASG analysis. Examination of Table XI reveals that in a 15-minute period the investigator elicited more than 50 scorable sentences in only 5 of the 12 subjects, while the mothers elicited more than 50 scorable sentences in 6 subjects. It should be observed, however, that in the 6 cases where the mothers elicited more than 50 utterances, in only 2 of the cases did they obtain more 
TABLE XI

AMOUNT OF UTTERANCES BY EACH SUBJECT OBTAINED

IN THE CLINIC AND IN THE HOME

IN A 15-MINUTE PERIOD

\begin{tabular}{rcc}
\hline Subject & $\begin{array}{c}\text { 非Utterances } \\
\text { in Clinic }\end{array}$ & $\begin{array}{l}\text { 非 Utterances } \\
\text { in Home }\end{array}$ \\
\hline 1 & 47 & 41 \\
2 & 47 & 32 \\
3 & 25 & $44 *$ \\
4 & 36 & 25 \\
5 & 65 & 61 \\
6 & 61 & 58 \\
7 & 55 & 33 \\
8 & 42 & $54 \%$ \\
9 & 16 & 8 \\
10 & 58 & 68 \\
11 & 69 & 55 \\
12 & 40 & \\
\hline
\end{tabular}

*Results obtained in a third examination

responses than the investigator.

The above data seem to support Toronto's findings (Toronto, 1972) in regard to amount of time and reticent subjects in the clinic. Toronto (1972) found in order to obtain more than 50 utterances from a reticent subject, the examiner might spend a minimum of 30 minutes eliciting the sample. With talkative subjects, however, 15 minutes are enough, which proved to be true with the only 5 talkative subjects of the total of 12 involved in this study (see Tables X and XI).

By way of a summary, one may say that although the speech and language clinician may elicit higher amounts of speech, there is a slight difference in favor of the quality of the language samples 
elicited by the mother in the home. This difference, however, is not statistically significant and does not invalidate those samples taken in the clinic. This author, therefore, believes that in terms of the Spanish-speaking population involved in this study, if a clinician invests time prior to the sample elicitation, the language samples elicited in the clinic setting may be considered to be representative of linguistic maturity. 
CHAPTER V

SUMMARY AND IMPLICATIONS

Summary

A common denominator to most studies concerning language acquisition is the elicitation of a corpus of a given number of spontaneous utterances which are representative of the child's linguistic maturity. This procedure, also called language sampling, is used daily by speech clinicians in their efforts to evaluate a child's language maturity and complexity.

Language samples are elicited and analyzed in the Hispanic countries without the availability of specific norms or procedures. Research considering the effects of different variables on the language sample, i.e., the possible differences between language samples elicited by mothers in the home setting and by clinicians in the clinic or school setting, is non-existent.

The primary purpose of the present study was to compare the quality of spontaneous language samples elicited from twelve low socioeconomic, normally developing, migrant Spanish-speaking subjects by their mothers in the home and by this investigator in the clinic. The subjects ranged in age from three years, one month to six years, nine months.

The essential question sought to determine if the comparison of language samples elicited in the home by the mothers and the language 
samples elicited in the clinic by the investigator yielded significant differences in syntactical language development as measured by the Developmental Assessment of Spanish Grammar (DASG) (Toronto, 1972, 1976). Comparison of DASG total scores and DASG individual category scores was made between the home and the clinic samples. Mean scores were determined for the subjects' performances in each setting. Differences between the means of the different results were analyzed utilizing a t-test. In addition, t-test analysis was conducted to determine the significance level of DASG scores when compared by age and sex in the clinic and in the home, and by order of examination. Results of the study indicated no statistically significant differences between the samples elicited in the clinic and in the home by the investigator and the mothers, although the subjects utilized more complex sentences in the home than in the clinic as demonstrated by the higher scores obtained in the Indefinite Pronouns and Noun Modifiers, Personal Pronouns, Primary Verbs, and Secondary Verbs categories. No statistically significant differences were found between sexes and the comparison of DASG scores by order of examination. Results of the comparison between age groups indicated a statistically significant difference in favor of the oldest group (Group IV; age range 6.8 to 6.9 ) when compared to a younger group (Group III; age range 5.2 to 5.10). A comparison of amount of responses elicited in a 15-minute period indicated a trend in favor of the investigator.

The results of the present study appear to support findings of studies conducted with English-speaking subjects. Although the speech-language clinician may elicit greater amounts of speech, there is a slight difference in favor of the quality of the language samples 
elicited by the mother in the home. This difference, however, is not statistically significant and does not invalidate those samples taken in the clinic. This author, therefore, believes that in terms of the Spanish-speaking population involved in this study, if a clinician invests time prior to the sample elicitation, the language samples elicited in the clinic setting may be considered to be representative of linguistic maturity.

\section{Implications for Clinic and Future Research}

\section{Clinical Implications}

The findings of this study support the results of studies by Scott et al. (1978), 01swang and Carpenter (1978), and Kramer et al. (1979), and indicate that the speech and language clinician can obtain a sample of speech which, although slightly lower in terms of syntactic development, is comparable to that used by the lower socioeconomic, migrant Spanish-speaking subject in the home.

Results of the present investigation demonstrate that for a lower socioeconomic, migrant Spanish-speaking population thirty minutes might be considered to be the minimum amount of time a clinician should spend in order to collect a desirable amount of utterances to conduct a significative DASG analysis.

In situations where the diagnosis is unclear, the language sample collected in the home setting by the mother might contribute to the thoroughness of the speech and language evaluation. The clinician, however, should be aware of the fact that the mother may not be able to spend thirty minutes talking with her child and that this 
might interfere with the collection of the amount of sentences needed to conduct the DASG analysis.

When collecting language samples in the clinical setting, the speech and language clinician should be aware of the advantage of eliciting the samples in the morning hours. This is especially true for very young subjects of this study who after their naps were observed to be tired and more reluctant to talk with the investigator.

Due to the fact most speech and language clinicians are Englishspeaking, white Americans, they are considered "outsiders" by the migrant Spanish-speaking population. It is, therefore, recommended, before any evaluation is initiated, for the clinician to learn not only the language but also to become familiar with the culture of this specific population.

\section{Research Implications}

There are a number of implications for further studies as indicated by this research. One would be to replicate the present study in a Latin American country with subjects of urban and rural areas. A second study could utilize the same design of the present research project but the age levels would be specifically controlled for four age groups and a larger population would be required on each age level. The outcome would indicate the actual differences or nondifferences between age groups.

In terms of sex differences in syntactic development it appears in lower socioeconomic, migrant Spanish-speaking subjects such a difference is non-existent. Further research, however, is needed. A third study, therefore, could be conducted in a Latin American country 
in which male and female subjects of different SES would be compared in terms of syntactic development in the clinic and in the home.

Another study would be to compare the quality of speech of Spanish-speaking subjects elicited by the clinician and the mother in the clinical environment. Once again, this study could be conducted with individuals classified in different SES in order to make comparisons inter- and intra-socioeconomic levels.

An interesting project would be to train a mother in language sample eliciting procedures, and to compare the obtained home results with those obtained by other mothers in the home setting with no previous training. This may show the trained mother is able to elicit better language samples, and to have the child on task for a longer period of time.

The "barrio" effect seems to interfere with the collection of language samples in the lower SES migrant Spanish-speaking population of the United States. Whether or not this is a unique phenomenon to this specific population has never been investigated. Future studies might be designed to investigate this effect. One of the studies would be to elicit language samples from a population in which half of the subjects have become acquainted with the investigator, while the other half have not. This may show the actual interference of the "barrio" effect in a lower SES, migrant Spanish-speaking population. A second study would be carried out in a Latin American country with lower SES subjects. The investigator in this case would not become acquainted with the subjects prior to the elicitation of the samples. This may show whether or not the "barrio" effect is unique to the 
lower SES Hispanics living in the United States.

A long-range investigation would be to standardize the DASG norms for the different SES Spanish-speaking population of a Latin American country. 


\section{BIBLIOGRAPHY}

BARLOW, M. C., Temporal reliability of Length Complexity Index. J. Comm. Dis. 16(2), 241-251 (1969).

BLOOM, L., Language Development: Form and Function in Emerging Grammars. Cambridge, Mass.: MIT Press (1970).

BROKEL, A., The provenience and present status of Spanish "se 1o." Linguistics $17(7 / 8), 659-670$ (1979).

BROWN, F. L., AMOS, J. R., and MINK, O. G., Statistical Concepts: A Basic Program. Second Edition. New York: Harper and Row Publishers (1975).

BROWN, R., A First Language. Cambridge, Mass.: Harvard University Press (1973).

CASTEEL, R. L., Comparison of amounts and types of communication used by language delayed children in home and clinic. Unpublished Doctora1 Dissertation. University of Oregon (1969).

CHOMSKY, C., The Acquisition of Syntax in Children from Five to Ten. Cambridge, Mass.: MIT Press (1969).

CONTRERAS, H., Sobre gramatica transformacional. In J. Carrillo: Lengua, Literatura, Folklore. Universidad de Chile (1967).

COWAN, P. A., WEBER, J., HODDINOT, B. A., and KLEIN, J., Mean length of spoken response as a function of stimulus, experimenter, and subject. Child Development 38, 191-203 (1967).

DALE, P. S., Language Development: Structure and Function. Second Edition. New York: Holt, Rinehart, and Winston (1976).

DARLEY, F. L., and MOLL, K. L., Reliability of language measures and size of language samples. JSHR 3,166-173 (1960).

DAVIS, E. A., The development of linguistic skill in twins, singletons with siblings and only children from age five to ten years. Child Welfare Monograph Series Number 14. Minneapolis: University of Minnesota Press (1937).

DE GONZALEZ, M., Como Detectar al Nino con Problemas del Habla. Mexico: Editorial Trillas (1976).

DE QUIROS, J. B., Los Grandes Problemas del Habla Infantil. Buenos Aires, Argentina: Casa Ares (1972). 
DEWEY, E., Infant Behavior. New York: Columbia University Press $(1 9 3 5 \longdiv { \text { . } }$

GARCIA, E. C., The Role of Theory in Linguistic Analysis of the Spanish Pronoun System. Amsterdam: North Holland Publishing Company (1975).

GESSEL, A. L., The First Five Years of Life: A Guide to the Study of the Preschool Child from the Yale Clinic of Child Development. Harper and Bros. (1940).

GESSEL, E. L., and AMATRUDA, C. S., Developmental Diagnosis: Normal and Abnormal Child Development: Clinical Methods and Pediatric Applications. New York: Hoeber (1947).

GONZALEZ, G., The acquisition of Spanish grammar by native Spanish speakers. Unpublished Doctoral Dissertation. University of Texas at Austin (1970).

HERRERA OROZCO, O., Professor, Instituto Nacional de la Comunicacion Humana. Mexico, D.F., Mexico (1979).

JAMES, S., The effect of 1 istener, age and the communicative situation on the politeness of children's directives. J. Psychol. Res. 7, 307-317 (1978).

JOHNSON, W., DARLEY, F. L., and SPRIESTERBACH, D. C., Diagnostic Methods in Speech Pathology. New York: Harper and Row (1963).

KERNAN, K. T., and BLOUNT, B. G., The acquisition of Spanish gramar by Mexican children. Anthropological Linguistics 8(9), 1-14 (1966).

KIRK, S. A., McCARTHY, J. J., and KIRK, A. D., Illinois Test of Psycholinguistic Abilities. Urbana: University of Illinois Press (1969).

KRAMER, C. A., JAMES, S. L., and SAXMAN, J. H., A comparison of language samples elicited at home and in the clinic. JSHD 44 , 321-330 (1979).

LABOV, W., Finding out about children's language. Speech delivered to the Hawaii Council of Teachers of English (1970).

LAWTON, F., Code shifting in Puerto Rican Spanish/English. Linguistics $17(3 / 4), 257-265$ (1979).

LEE, L. L., Developmental Sentence Analysis. Evanston, I1l.: Northwestern University Press (1974).

LEE, L. L., and CANTER, S., Developmental Sentence Scoring: A clinical procedure for estimating syntactic development in children's spontaneous speech. JSHD 36, 315-340 (1971). 
LINARES-ORANA, N., The language evaluation of preschool Spanishspeaking Puerto Rican children. Unpublished Doctoral Dissertation. Northwestern University (1975).

LINARES-ORANA, N., and SANDERS, L. J., Evaluation of syntax in threeyear-old Spanish-speaking Puerto Rican children. JSHR 20(2), 350-357 (1977).

IINDHOLM, K. J., and PADILLA, A. M., Child bilingualism: Report on language mixing, switching and translations. Linguistics $17(3 / 4), 23-43$ (1979).

LONGHURST, T., and FILE, J., A comparison of the developmental sentence scores from Head Start children collected in four conditions. LSHSS 8(1), 54-64 (1975).

LONGHURST, T., and GRUBB, S., A comparison of language samples collected in four situations. LSHSS 5, 71-78 (1974).

LONGHURST, T., and SCHRANDT, T. A., Linguistic analysis of children's speech: A comparison of four procedures. JSHD 38(2), 240-249 (1973).

MATHIS, J., Comparison of amounts of verbal response elicited by a speech pathologist in the clinic and a mother in the home. Unpublished Master's Thesis. Portland State University (1970).

McCARTHY, D. A., The language development of the preschool child. Child Welfare Monograph Series Number 4. Minneapolis: University of Minnesota Press (1930).

McCARTHY, D. A., Language development in children. In L. Carmichae 1 (Ed.): Manual of Child Psychology. New York: Wiley (1954).

NELSON, S. L., Comparison of amounts of verbal response elicited by a speech pathologist and a mother in the clinic. Unpublished Master's Thesis. Portland State University (1972).

NICE, M. M., Length of sentences as criteria of a child's progress in speech. J. Educ. Psych. 16, 370-379 (1926).

OLSWANG, L., and CARPENTER, Q., Elicitor effects on the language obtained from language impaired children. JSHD 43(2), 76-88 (1978).

PEARCE, L. K., A comparative study of language deficits of reservation and urban Indian children. Unpublished Master's Thesis. Portland State University (1978).

PIAGET, J., The Language and Thought of the Child. New York: Harcourt, Brace (1926). 
RATUSNIK, D. L., RATUSNIK, C. M., and SATTINGER, K., Short form application of the Screening Test to Spanish Grammar and the Northwestern Syntax Screening Test to latino children. LSHSS 9(4), 220-233 (1978).

RUEDA, R., and PEROZZI, J. A., A comparison of two Spanish tests of receptive language. JSHD 42, 210-214 (1977).

SCHNEIDERMAN, M., A study of the relationship between articulatory ability and language ability. JSHD 20, 359-363 (1955).

SCOTT, C., TAYLOR, A., and WHITE, C., A comparison of home and clinic gathered samples. JSHD 43(4), 482-495 (1978).

SHRINER, T. H., A comparison of selected measures with psychological scale values of language development. JSHR 10,825-835 (1967).

SOLANO DE ARAYA, S., Professor, Programa de Trastornos de la Comunicacion. Universidad de Costa Rica, San Pedro. San Jose, Costa Rica (1980).

TEMPLIN, M. C., Certain language skills, in children. Child Welfare Monograph Number 26. Minneapolis: University of Minnesota Press (1957).

TORONTO, A. S. A., A developmental Spanish language analys is procedure for Spanish speaking children. Unpublished Doctoral Dissertation. Northwestern University (1972).

TORONTO, A. S. A:, Screening Test of Spanish Grammar. Evanston, I11.: Northwestern University Press (1973).

TORONTO, A. S. A., Developmental Assessment of Spanish Grammar. JSHD $41(2), 150-169$ (1976).

TREJOS DE LAFENDT, M. E., Professor, Centro Nacional de Educacion Especial "Fernando Centeno Guel1," Departamento de Trastornos de la Comunicacion, Guadalupe. San Jose, Costa Rica (1980).

WILSON, M. E., A standardized method for obtaining a spoken language sample. JSHR 12, 95-102 (1969).

WINITZ, H., Language skills of male and female kindergarten children. JSHR 2, 377-386 (1959). 
APPENDIX A

CONSENT FORM FOR PARTICIPATION OF THE CHILD

\section{ENGLISH:}

I, hereby agree to let my child participate as a subject in the research project conducted by SOLEDAD CHAVARRIA, graduate student of the SPEECH AND HEARING SCIENCES PROGRAM at PORTLAND STATE UNIVERSITY.

The purpose of this investigation has been thoroughly explained to me. I understand the participation of my child involves talking about some pictures and/or toys, or conversing with me. The same procedure will be used by the investigator when she talks with my child at school. I understand all conversation will be recorded and that my child's utterances will be analyzed.

SOLEDAD CHAVARRIA has offered to answer any questions I may have about the project. I have been assured that all information will be kept confidential and that the identity of all subjects will remain anonymous.

Mother

Date

Investigator

Date

\section{SPANISH:}

Yo, autorizo a mi hijo a participar en el proyecto de investigacion dirigido por SOLEDAD CHAVARRIA, estudiante a nive 1 de pos-grado en el PROGRAMA DE AUDICION Y LENGUAJE de PORTLAND STATE UNIVERSITY.

El proposito de este proyecto me ha sido explicado en su totalidad. Entiendo que la participacion de $\mathrm{mi}$ hijo involucra el conversar conmigo acerca de los juguetes y/o laminas que estaremos viendo. E1 mismo procedimiento sera utilizado por la investigadora, cuando ella hable con mi hijo/a en la escuela. Se que todas las conversaciones se an grabadas para luego ser analizadas.

SOLEDAD CHAVARRIA se ha ofrecido para contestar todas las preguntas que tenga acerca del proyecto. Se me ha asegurado que toda la 
informacion sera considerada confidencial y que, la identidad de todos los participantes permanecera anonima. 


\section{APPENDIX B}

\section{CONSENT FORM FOR PARTICIPATION OF THE MOTHER}

\section{ENGLISH:}

I, hereby agree to participate in the investigation project conducted by SOLEDAD CHAVARRIA, graduate student of the SPEECH AND HEARING SCIENCES PROGRAM at PORTLAND STATE UNIVERSITY.

The purpose of this project has been explained to me. I understand that my participation involves talking with my child about toys and/or pictures and that this language sample will be tape-recorded.

SOLEDAD CHAVARRIA has offered to answer any questions I may have about the project. I have been assured that all information will be kept confidential and that the identity of all subjects will remain anonymous.

Mother

Date

Investigator

Date

\section{SPANISH :}

Yo, estoy de acuerdo en participar en el proyecto de investigacion dirigido por SOLEDAD CHAVARRIA, estudiante a nivel de pos-grado en el PROGRAMA DE AUDICION Y LENGUAJE de PORTLAND STATE UNIVERSITY.

El proposito de este proyecto se me ha explicado en su totalidad. Entiendo que mi participacion involucra el conversar con $\mathrm{mi} \mathrm{hijo} / \mathrm{a}$ acerca de unos juguetes y/o dibujos, que esta muestra de lenguaje sera grabada.

SOLEDAD CHAVARRIA se ha ofrecido para contestar todas las preguntas que yo tenga acerca del proyecto. Se me ha asegurado que todo la informacion sera considerada confidencial y que, la identidad de todos los participantes permanecera anonima. 


\section{APPENDIX C \\ INSTRUCCIONES PARA LA MADRE SOBRE COMO EVOCAR \\ UNA MUESTRA DE LENGUAJE}

1. Busque un lugar tranquilo en su casa donde usted y su nino puedan conversar libremente por treinta minutos.

2. Sientense en el suelo o, alrededor de una mesa o en donde ustedos dos se sientan comodos.

3. Converse con su nino acerca de las cosas que hace/hizo en la escuela, or acerca de sus amigos, o, su programa favorito en la TV, lugares que les gusta ir, 0 , cosas con las que le gusta jugar.

4. Use dibujos, retratos, juguetes, etc. Recuerde que 10 mas importante es que el nino $\mathrm{HABLE}$, $\mathrm{HABLE}$, HABLE. Utilize todo 10 que este a su alcance $e$ imaginacion porque lo que queremos es obtener la mayor cantidad de conversacion posible por parte de su $\mathrm{hijo/a}$.

Tiene alguna duda con respecto a lo que usted va a hacer? 
APPENDIX D

DASG CATEGORIES AND WEIGHTED SCORES

\begin{tabular}{|c|c|c|c|}
\hline ore & $\begin{array}{l}\text { Indefinite } \\
\text { Pronouns }\end{array}$ & $\begin{array}{l}\text { Personal } \\
\text { Pronouns }\end{array}$ & $\begin{array}{l}\text { Primary } \\
\text { verbs }\end{array}$ \\
\hline 1 & & (2) $\frac{\text { reflexives: }}{\text { se, me, te }}$ & $\begin{array}{l}\text { (1) single pres- } \\
\text { ent tense: vengo, } \\
\text { vienes, viene } \\
\text { copular es, son, } \\
\text { esta. soy, estoy } \\
\text { estás } \\
\text { (2) est + v + ndo } \\
\text { ith present tense } \\
\text { only: Está jugando. }\end{array}$ \\
\hline 2 & $\begin{array}{l}\text { (1) este, esta, } \\
\text { esto, ese, esa. } \\
\text { eso }\end{array}$ & $\begin{array}{l}\text { (1) lst and 2nd } \\
\text { person: yo, tú, } \\
\text { Ud., mi, mío, tưgo } \\
\text { suyo, su }\end{array}$ & $\begin{array}{l}\text { (3) plural conjuga- } \\
\text { tions, } \\
\text { simple past tense, } \\
\text { irperatives-any } \\
\text { form, } \\
\text { subjunctives }\end{array}$ \\
\hline 3 & $\begin{array}{l}\text { (2) la, lo, más, } \\
\text { todo, toda, otro, } \\
\text { otra } \\
\text { (5) nada, primero }\end{array}$ & $\begin{array}{l}\text { (3) 3rd person: } \\
\text { él, ella, de él, } \\
\text { el ella } \\
\text { (4) sipqular Do E } \\
\text { IO: se, me, te, } \\
\text { Ie, ti } \\
\text { Also: conmigo, } \\
\text { contigo }\end{array}$ & $\begin{array}{l}\text { (4) copula other } \\
\text { than score l: fué. } \\
\text { era, fuid } \\
\text { (4) past perfect } \\
\text { terge: -aba and } \\
\text {-ia endings }\end{array}$ \\
\hline 4 & $\begin{array}{l}\text { (3) all plurals } \\
\text { up to and includ- } \\
\text { ing this level } \\
\text { (4) algo, alguien } \\
\text { alguno, alguna, } \\
\text { poco, mucho, uno, } \\
\text { dos, tres.... }\end{array}$ & $\begin{array}{l}\text { (6) plusals: } \\
\text { nosotros, nuestro, } \\
\text { ellos, ellas, Uds. } \\
\text { mis, tus, sus, } \\
\text { etc. }\end{array}$ & \\
\hline 5 & $\begin{array}{l}\text { (6) cualquier, } \\
\text { ambos, cada, nadie }\end{array}$ & $\begin{array}{l}\text { (7) plural Do \& IO } \\
\text { les, los, nos }\end{array}$ & $\begin{array}{l}\text { (5) poder or deber } \\
+v+r \\
\text { Conditional tense: } \\
\text { podria, etc. }\end{array}$ \\
\hline 6 & $-\cdot \quad-$ & & $\begin{array}{l}\text { (6) haber + v + do } \\
\text { alf tenses }\end{array}$ \\
\hline 7 & $\begin{array}{l}\text { (7) vários, unico, } \\
\text { próxino, áltimo. } \\
\text { segundo, tercero, } \\
\text { etc. } \\
\text { plus female gen- } \\
\text { ders }\end{array}$ & $\begin{array}{l}\text { (8) relative pro- } \\
\text { nouns: que, quien } \\
\text { cual }\end{array}$ & $\begin{array}{l}(7) \text { baber + esitado } \\
+V+\text { ado }\end{array}$ \\
\hline 8 & & & $\begin{array}{l}\text { (8) poder or deber } \\
+ \text { haber + estado + } \\
\text { ndo } \\
\text { Passives }\end{array}$ \\
\hline
\end{tabular}




\begin{tabular}{|c|c|c|c|}
\hline score & $\begin{array}{l}\text { Secondary } \\
\text { verbs }\end{array}$ & Conjunctions & $\begin{array}{c}\text { Interrogative } \\
\text { kords }\end{array}$ \\
\hline 1 & $\cdot$ & & $\begin{array}{l}\text { qué } \\
\text { quién } \\
\text { donde }\end{array}$ \\
\hline 2 & $\begin{array}{l}\text { (1) ir plus in- } \\
\text { finitive: va a } \\
\text { salir. Iba a ven- } \\
\text { ir. } \\
\text { Complementing in- } \\
\text { initive after any } \\
\text { other verb }\end{array}$ & & $\begin{array}{l}\text { cuándo } \\
\text { para qué } \\
\text { crmo }\end{array}$ \\
\hline 3 & $\begin{array}{l}\text { (4) Present part- } \\
\text { iciple: } \\
\text { Va llorando. } \\
\text { Anda buscando. }\end{array}$ & & $\begin{array}{l}\text { por qué } \\
\text { de quí́n } \\
\text { de qué } \\
\text { cuánto (s) }\end{array}$ \\
\hline 4 & $\begin{array}{l}\text { (3) Non-comple- } \\
\text { menting infini- } \\
\text { tives of purpose: } \\
\text { se pararon a ju- } \\
\text { gar. para salir. } \\
\text { de venir } \\
\text { Also infinitive } \\
\text { with interroq. } \\
\text { word: sé donde ir. }\end{array}$ & $\begin{array}{l}\text { (1) y } \\
\text { que }\end{array}$ & cuál \\
\hline 5 & & $\begin{array}{l}\text { (2) porque } \\
\text { para que } \\
\text { como } \\
\text { (3) pero, cuando }\end{array}$ & \\
\hline 6 & & $\begin{array}{l}\text { (4) donde,entonces } \\
\text { (6) mientras, } \\
\text { hasta, antcs, } \\
\text { desde, después, } \\
\text { aún, menos que }\end{array}$ & \\
\hline 7 & $\begin{array}{l}\text { (5) Passive com- } \\
\text { plement of infin- } \\
\text { itive: Quicro } \\
\text { estar vestido }\end{array}$ & $\begin{array}{l}\text { (5) } 0 \\
n i \\
8 i\end{array}$ & \\
\hline 8 & $\begin{array}{l}\text { (6) Gerund or in- } \\
\text { finitive used as } \\
\text { Bubject: Fumar } \\
\text { es malo. } \\
\text { Caminando le hace } \\
\text { bien. }\end{array}$ & $\begin{array}{l}\text { (7) por lo tanto. } \\
\text { sin embargo, no } \\
\text { obstante. sino. } \\
\text { etc. }\end{array}$ & \\
\hline
\end{tabular}




\section{APPENDIX E}

DEVELOPMENTAL ASSESSMENT OF SPANISH GRAMMAR SCORE SHEET

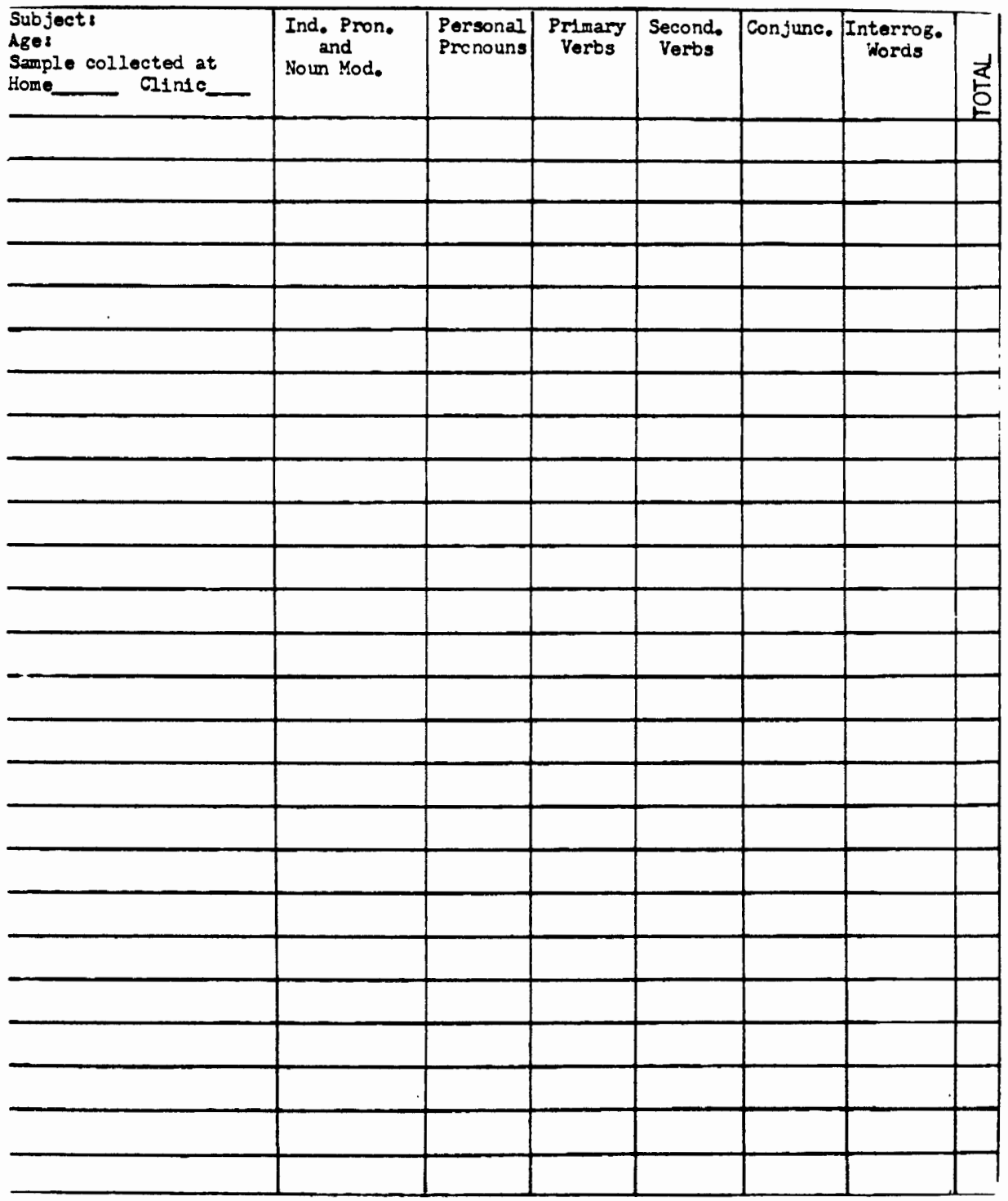




\section{APPENDIX F}

TYPICAL LANGUAGE SAMPLE ELICITED BY THE MOTHER IN THE HOME

1. yo no se/

2. jugue con los ninos/

3. comi galletas y leche/

4. Y luego comimos pan con hot dog y ketchup/

5. jugamos al monstruo/

6. a mi me gusta jugar y dibujar/

7. voy a escribir y jugar/

8. una nina se Ilama griselda/

9. $y$ otra que se llama rosi/

10. ellos son mis hermanos/

11. 1o estan bautizando/

12. es de clemencia/

13. esta en la cama/

14. Ia bebita estaba chiquita/

15. 1a bebita tiene una pelota/

16. viven en mexicol

17. es mi abuelita/

18. son los amiguitos de la escuela/

19. nos estan retratando/

20. estan peleando/

21. se parece como chule/

22. amanecio lloviendo/ 
23. estuvo bonito dial

24. que haya so1/

25. porque el crecio primero y luego yo/

26. porque yo perdi/

27. yo no gane nadal

28. que es//

29. como se hace esto ma//

30. cuando este grande voy a ir con mi abuelito/

31. me lo compraste tu/

32. no sabes//

33. asina mira/

34. me dijo vete $\mathrm{pa}^{\prime}$ mexico/

35. ayer no ahorita te dijo/

36. no me acuerdo como se Ilama/

37. el grandote se llama ignacio/

38. $y$ como te llamas tu mami//

39. yo me 1 lamo(a) de que//

40. que me bane en el parque/

41. cuando tenga asina voy/

42. bailaron/

43. como bailan los ninos/

44. yo quiero que me compres otras/

45. su hermanito del flaco esta en mi clase/

46. 1e estan poniendo su abrigo/

47. la mujer 10 regano porque se metio y no podia salir/

48. ese va a mi clase/ 
49. ya se quebro tu bote mami/

50. una muchachita no mas tengo en mi clase/ 


\section{APPENDIX G}

TYPICAL LANGUAGE SAMPLE ELICITED BY THE INVESTIGATOR IN THE CLINIC

1. para que es la munequita//

2. santa claus me la trajo dos/

3. yo no sel

4. vuela/

5. se cambia la ropa/

6. tengo dos hermanitos y tres hermanitas/

7. porque unos senores los mataron/

8. se los llevo al doctor/

9. ni me compraron/

10. tiene una capal

11. $y$ asi vuela/

12. si si tiene amigos/

13. no esta en la escuelal

14. yo y marta y mi otra hermanita se llama maria de jesus/

15. nunca mi papi ni me deja ir/

16. porque no/ ahorita fuimos a la fresal

17. Y mami corto fresas/

18. $Y$ me trajo fresas a mi para que me las comiera/

19. Y me las comi todas/

20. no me dan muchas/

21. estan viendo a los animales/

22. no mas esta viendolos comiendo/ 
23. vemos muchos animales/

24. se va a bajar/

25. pero voy a ir a mirar los animales/

26. 1e duele las muelas/

27. donde van ellos//

28. se mete donde estan las ninas esas/

29. como es//

30. mira lo que hace/

31. ay se cayo/

32. que esta haciendo ella//

33. porque se anda durmiendo en las camas de bebito/

34. y el se anda columpiando en el arbol/

35. no yo no soy grande/

36. para que es esto//

37. quiero oir esto/

38. $y$ alli oye uno ahi/

39. no a mi no me gustal

40. pues mira soy china/

41. puedo hacer otra//

42. eㅡ solte la tobillera/

43. se fue/

44. no pero el se echo primero/

45. nada mas como los pelos se me pararon/

46. Y mi hermano me tallo con un estropajo/

47. porque yo no alcanzo el lavadero/

48. $Y$ me queda hasta aqui/ 
49. yo no se abrir la llave para lavar el estropajo/

50. puedo levantar eso/ 